\title{
Çoğulculuk ve Sosyal Bilgiler Dersi Öğretim Programları (1924-2018): Eleştirel Bir Analiz ${ }^{1}$
}

\section{Pluralism and Social Studies Curricula (1924-2018): A Critical Analysis}

\author{
Mustafa CEYLAN DiD, Dr., İngilizce Öğretmeni, metuceylan@gmail.com \\ Hünkar KORKMAZ D, Prof. Dr., Hacettepe Üniversitesi, Eğitim Bilimleri Enstitüsü, hunkar@hacettepe.edu.tr
}

Ceylan, M. ve Korkmaz, H. (2021). Çoğulculuk ve Sosyal Bilgiler Dersi Öğretim Programları (1924-2018): Eleştirel Bir Analiz. Batı Anadolu Eğitim Bilimleri Dergisi, 12(2), 469-499.

Öz. Bu çalışma kapsamında Türkiye'deki eğitim programlarının çoğulculuk perspektifinden eleştirel program teorisi yaklaşımı kullanılarak incelenmesi amaçlanmıştır. Araştırmada eleştirel program teorisinin ve çoğulcu felsefenin önemli varsayımlarından olan programların her bir bireyi kapsayıcı bir hale getirilmesinin gerekliliği üzerinde durulmuştur. Nitel yaklaşımla tasarlanan araştırmada bütüncül çoklu durum çalışması deseninden yararlanılmıştır. Araştırmanın veri setini 1924-2018 yılları arasında yayımlanan sosyal bilgiler dersi öğretimine yönelik hazırlanan resmi öğretim programları oluşturmaktadır. Araştırmada veriler çoğulculuğun boyutlarına ilişkin belirlenen kod ve temalar ile eleştirel analiz soruları kullanılarak betimsel analiz yoluyla analiz edilmiştir. Araştırma sonucunda programların "teorik ve ideolojik arka planı" ile " birey ve bireysel/toplumsal farklılıklara", "düşünme becerilerine", "sosyal sorunlara", "çoğulcu değerlere" yönelik bulgulara ulaşılmıştır. Ulaşılan bulgular doğrultusunda; programların ideolojik bir metin olduğu, programlarda bireysel farklılıklara yeterince yer verilmediği, öğrencilere üst-düzey düşünme becerilerinin kullanımına uygun bir ortam sağlanamadığı, pasif vatandaşlık algısının yüceltildiği ve programlarda bireysel değerlerden çok toplumsal değerlere yer verildiği çıkarımlarında bulunulmuştur. Çoğulculuk bağlamında programların geçmişine ve bugününe ilişkin yapılan eleştirel tespitlerin eğitimi etkileyen ve eğitimden etkilenen tüm bireylerin programa dair anlayışlarının derinleşmesine katkı sağlayacağı umulmaktadır.

Anahtar Kelimeler: Çoğulculuk, Çoğulcu eğitim programı, Eleştirel program teorisi, Sosyal bilgiler dersi öğretim programları.

\begin{abstract}
In this study, it is aimed to examine curricula in Turkey from the perspective of pluralism by using critical curriculum theory. This research was designed with holistic multiple case study, a design of qualitative research method. The data set of the study consists of official curricula regarding social studies instruction having been prepared since the foundation of Turkish Republic (1924-2018). The data was analyzed with descriptive analysis by using codes, themes and critical analysis questions, developed with regard to the dimensions of pluralism. At the end of the study, the findings regarding "theoretical- dialogical background", "individual and individual- social differences", " "thinking skills", "social problems" and "pluralistic values" were revealed. It is hoped that critical implications on the past and present situation of the curricula from a pluralistic perspective will help all of the individuals who influence education and are influenced by education deepen their understanding concerning the curriculum.
\end{abstract}

Keywords: Pluralism, Pluralistic curriculum, Critical curriculum theory, Social studies curricula.

\footnotetext{
${ }^{1}$ Bu makale "Sosyal Bilgiler Dersi Öğretim Programlarının (1924-2018) Çoğulculuk Perspektifinden İncelenmesi" isimli doktora tezinden yararlanılarak hazırlanmıştır.
} 


\section{Extended Abstract}

Introduction. Today, not only the societies which have multicultural demographic structures but also all societies need to redesign their curricula from a pluralistic perspective. Therefore, ensuring different cultures to develop tolerance and empathy towards each other should be one of the most important aims of the curricula. The curricula which do not carry this aim are not compatible with both the culture of each individual country and the culture of world that is getting more and more pluralistic day by day. In this study, it is aimed to examine curricula in Turkey from the perspective of pluralism with the approach of critical curriculum theory.

Method. To achieve this aim, the data set of the study consists of official curricula regarding social studies instruction having been implemented since the foundation of Turkish Republic (1924-2018). This study was designed with multiple case study, which is a method of qualitative approach. The data was analyzed by using the methods of content and descriptive analysis. For content analysis, five dimensions were created. Descriptive analysis was conducted with "Questions for Critical Analysis of Curriculum from a Pluralistic Perspective". Both the questions for critical analysis and the dimensions of pluralism including code-themes were determined by the researcher after a long and detailed literature review on the concepts such as; pluralism, critical curricula.

Results. After critical examination of social studies curricula having been developed and implemented since the foundation of Turkish Republic from the perspective of pluralism, the following findings were revealed;

Regarding theoretical and, ideological background: It was found that every ruling party had renewed the curricula all over again without aiming to create any inter-coherence among curricula throughout the history of Turkish Republic. It was also concluded that the curricula had been used as a vehicle for ideological indoctrination by the state. Furthermore, it is dramatic to rote that the curricula have been developed without aiming to construct a social consensus.

Regarding individual and individual-social differences: It was inferred that the curricula had been designed with an approach that prioritizes the society instead of individual. So, it is possible to observe that the curricula emphasized the concepts such as; society, community, hormany with society and collectivity much more frequently than the concepts such as; individual, individuality, individual/ ethnic/ cultural/ language etc. differences. In addition, it is essential to note that there have been traces of rhetoric, which instigates sexual/ gender discrimination and reinforces biases concerning gender roles.

Regarding thinking skills: It was deduced that although it was possible to observe a failure in creating necessary conditions to make students acquire and improve these skills in practice. There can be listed a number of reasons for this failure such as; lack of necessary equipments problems related to teachers competences, strict structure of the curricula, which does not allow any changes, ideological polarizations and authoritarian philosophy of decision-makers.

Regarding sensitivity to social problems: It was implied that the curricula wished to educate citizens who are obedient to authority, convergent with majority and do not question or criticize social norms. In addition alternative ways to influence democratic decision-making processes were perspective. Furthermore, it was understood that only sterilized issues and topics. Which do not allow questioning, discussing and criticizing the deeply rooted social norms, were included in the curricula.

Regarding pluralistic values: It was observed that the values of self scarification, nationalism, patriotism, responsibility, cooperation, collaboration and unity were admired in the curricula. The 
biggest reason for this admiration might be the philosophy that aims to construct a homogeneous social structure rather than pluralistically-formed society. It was also deduced from the curricula that interpreting universal values such as; respect for differences, tolerance, sensitivity to human rights from a nationalist perspective restricts their real meanings.

Discussion and Conclusion. In the light of the findings given above, the following suggestions were made;

$\checkmark$ The curricula should be planned, developed, implemented, evaluated and renewed on the basis of pluralism with pluralistic principles and methods

$\checkmark$ As a requirement of pluralistic democracy, social consensus should be realized in determining educational policies

$\checkmark$ All people influencing and influenced by education should reconceptualize their belief, knowledge and opinions, regarding the meaning of education from a pluralistic perspective

$\checkmark$ The curricula should provide as many individualized options as possible for students and they should be as flexible as possible for teacher to be able to make individual changes

$\checkmark$ Individuals should be given a right to choose and participate in decision-making processes in every stage of curriculum development

$\checkmark$ Centralist and standard curriculum development approach should be abandoned

$\checkmark$ Reproduction of values. Which cause sexual/gender discrimination through curriculum should be prevented

$\checkmark$ All curricula, especially social studies curriculum, should be designed in an intellectually fairer way with multiple perspectives. Which allow questioning and criticizing

$\checkmark$ All curricula, especially social studies curriculum, should be structured on the basis of themes such as; individual rights, human rights, democracy, civilian society, equity, fraternity, liberty/freedom

$\checkmark$ All curricula should be planned to allow discussion of the problems related to living together

It is hoped that the critical implications regarding past and present situation of the curricula from the pluralistic perspective will help all of the educators, especially teachers and curriculum researchers, deepen their understanding in relation to the future of the curricula in Turkey. 


\section{Giriş}

20. yüzyılın başlarında ortaya atılan Görecelik Kuramı, Kaos Teorisi, Kuantum Fiziği şeklinde sıralanabilecek bilimsel geliş̧meler evrene ilişkin temel varsayımların sorgulanmasına neden olduğu gibi; insan öğrenmesine ilişkin bakış açısında da köklü bir değişimin başlangıcını oluşturmuştur (Akbaş, 2013; lonne, 1995). Söz konusu bu değişim Türkiye'de daha çok Anglo-Amerikan yaklaşımın etkisiyle Progressivizm / Ilerlermecilik olarak bilinse de; Fransa'da Education Nouvelle, italya'da Attivizma, Almanya'da ise Reform Pedagojik kavramlarıyla sembolleşmiştir (Hesapçıoğlu, 2009). O dönemdeki eğitime yönelik; yapay biçimde belirlenen ders saatleri, esnekliğe izin vermeyen katı program anlayışı, sadece kitap temelinde yürütülen öğretim, bağımsız çalışma süresinin kısıtılı̆̆ı, toplu eğitimin tekdüzeliği vb. eleştirileri (Hesapçıoğlu, 2010) yönelten bu yeni eğitim anlayışının savunucuları aslında kendilerinden sonra ortaya çıkan ve okullara ilişkin sorgulayıcı bir bakış açısının gerekliliğine vurgu yapan eleştirel pedagojinin de ilham kaynağını oluşturmuşlardır (Apple, 2012).

Bilimsel bir alan olarak eğitim programları alanının doğuşu ve gelişimi de genel anlamda eğitime yönelik sorgulayıcı tutumun izlerini taşımaktadır. Zira o dönemdeki eğitimin yeni bir bakış açısıyla yapılandırılması gerektiğini savunan Bobbit, Chartes, Tyler gibi eğitimciler eğitim programlarına ilişkin görüşleriyle bu alanın doğuşuna öncülük etmişlerdir (Ornstein ve Hunkins, 2003). Ancak söz konusu bu eğitimciler kendilerini program geliştirmenin en etkili yolunu bulma; program geliştirme aşamalarının ilke ve yöntemlerini ortaya koyma vb. mekanik bir anlayışla sınırlandırarak (Apple, 2012) programın hem sebebi hem de amacı bireyi unutmuşlardır (Giroux ve Purpel, 1983). Böylece hâlihazırda eleştirdikleri eğitim anlayışının daha etkili bir şekilde uygulanmasına istemeden de olsa sebep olmuşlardır. Zira programa mekanik bir anlayışla yaklaşmaları öğretmen ve öğrencinin programdan izole edilmesi; dolayısıyla onlara hazır ve standart bir metin sunma geleneğinin devam etmesi sonuçlarını doğurmuştur (Green, 2003).

Bununla birlikte 20. yüzyılın ikinci yarısından itibaren Freire, llich, Apple gibi eğitimcilerin genel anlamda eğitim sistemine yönelik eleştirileri ve Schwab (1971) gibi araştırmacıların eğitim programları alanına ilişkin yeni bir bakış açısının gerekliliğine vurgu yapması "Eleştirel Program Teorisi" yaklaşımının temelini oluşturmuştur. Özellikle Pinar'ın (1999) görüşleri ile şekillenen, program geliştirme aşamalarının katı bir şekilde takip edildiği Tyler tarzı program anlayışını reddeden ve programı insancıl, varoluşçu, fenomonolojik, estetik bakış açılarıyla anlamayı savunan bu yaklaşım, program alanında etkisini giderek daha çok hissettirmektedir (Bümen ve Aktan, 2014).

\section{Eleştirel Program Teorisi}

Eleştirel program teorisi eğitim, program ve okula yönelik eleştirel ve sorgulayıcı bir bakış açısına sahiptir (Pinar, 2003). Planlı yaşantılar düzeneği şeklindeki mekanik program tanımlamasına şiddetle karşı çıkmakta; programın karmaşık bir iletişim ve derin bir diyalog olarak araştırılmasının gerekliliğini savunmaktadır (Pinar, Reynolds, Slattery ve Taubman, 1995). Bu nedenle eleştirel program teorisyenlerine göre program yazılı bir metinden ziyade eğitimi etkileyen ve eğitimden etkilenen tüm birey ve gruplara yönelik çıkarımların yapılabileceği sembolik bir sunumdur (Freinberg, 1998).

Sembolik bir sunum olması yönüyle program siyasidir, ırksaldır, otobiyografiktir, fenomonolojiktir, teolojiktir, cinsiyetçidir ve bu olgular ışı̆ıında analiz edilmelidir (Pinar, 2004). Diğer bir ifade; eleştirel eğitim teorisini benimseyen araştırmacılar program metinlerinde zarif sessizlikler şeklinde verilen ideolojik mesajları, herkes için genel geçer ilke ve yöntemleri aramaktan daha önemli bir tartışma konusu olarak gören eğitimcilerdir (Apple, 1985). Bu doğrultuda programlar başta olmak üzere okullar ile diğer pedagojik alanları sorgulama (Apple, 2012), öğretim politikalarının her bir 
bireyin eşit şekilde yararlanmasını sağlama (Solomon, 1998), ve daha insancıl bir eğitim için nelerin değiştirilmesi gerektiğine yönelik öneriler sunma (Pinar, 1999) eleştirel geleneğin yöntemleridir. Dolayısıyla eleştirel program teorisine göre genelde eğitime özelde ise programa ilişkin tüm düşünce, inanış ve olgular daha bireysel, eşitlikçi ve insancıl bir bakış açısıyla yeniden kavramsallaştırılmalıdır (Pinar, 2004).

Eleştirel program teorisi söz konusu yeniden kavramsallaştırma sürecinde entelektüel keşif, merak, sorgulama, bireysel özgürlük, öz yansıtma, bireyselleştirilmiş, farklılaştırılmış ve zenginleştirilmiş programlar gibi olguları da ön plana çıkarmaktadır (Pinar vd., 1995). Bu doğrultuda ırk ayrımcılı̆̆ı, etnik ayrımcılık, program-siyaset ilişkisi, program-din ilişkisi, program-tarih ilişkisi, cinsiyet, cinsel yönelim, popüler kültür, otobiyografi, fenomonoloji, post pozitivizm, psikanaliz vb. kavram ve konular etrafında araştırmalar yapılmasının gerekliliğini savunmaktadır (Pinar, 2004)

Eleştirel program teorisinin ısrarla vurguladığı ve ön plana çıkardığı kavram, olgu ve araştırma konularına bakıldığında toplumdaki her bir bireyin ya da grubun değer ve görüşlerine programın tüm süreçlerinde yer vererek daha kapsayıcı, kültüre daha duyarlı ve çeşitlilikleri olabildiğince teşvik eden bir yaklaşım olduğu çıkarımında bulunulabilir (Biesta, 2013). Dolayısıyla eleştirel program teorisyenlerinin eğitim ve programa ilişkin güçlü bir şekilde savundukları görüşlerinin arka planında bireylerin eğitimlerinin planlanmasında cinsiyet, ırk, etnik köken, sosyoekonomik durum, kültür, dil, din, siyasi görüş, politik duruş farklııklarının göz önünde bulundurulmasını ifade eden "çoğulculuk" paradigmasının olduğu söylenebilir (Banks, 2007). Bu nedenle çoğulculuk hem eleştirel program teorisinin felsefesini anlamak açısından hem de bireysel ve toplumsal çeşitliliklere izin veren; dahası onları teşvik eden daha kapsayıcı bir eğitim için gerekli anlayışı temsil etmektedir (Schachner, 2017).

\section{Çoğulculuk}

Programın sadece çoğunluğun değil, çoğunluk dışında kalan birey ya da grupların da kendisine yer bulabileceği bir iklim inşasına katkı sağladığı ölçüde kapsayıcı ve bütünleştirici olduğu (Appelbaum, 2002) düşüncesine dayanan çoğulcu paradigma, farklılıkların zenginlik olarak görülmesini savunmaktadır (Cortes, 1991). Zira çoğulculuğun tanımındaki farklıık kelimesi aslında konuşma ve düşünme çeşitliliğindeki özgürlüğü ifade ederken; zenginlik kelimesi ise farklı özgeçmişlerden herkesin ilgi, ihtiyaç ve yeteneklerini geliştirebileceği medeni bir toplumu işaret etmektedir (Cırık, 2008). Dolayısıyla çoğulcu paradigmaya göre farklııklar yönetilmesi veya çözülmesi gereken sorunlar değildir; farklılıklar toplumdaki normların çeşitli varyasyonlarından ibaret de değildir (Alvarez, 2018). Farklılıklar olması istenen, teşvik edilen, gelişim ve ilerleme için yararlanılması gereken eşsiz bir kaynaktır; farklılıklar bağımsız değerler olarak kabul edilmesi gereken olgulardır (Appelbaum, 2002).

Kültürel farklılıkların ödüllendirilmesi temelinde yapılan bir programın ırk, etnik köken, cinsel yönelim, cinsiyet, yaş, engelli olma, sosyal sınıf, eğitim, dini tercih vb. farklılıklara sahip bireylerin birbirlerinden öğrenmelerinin değerini vurgulaması son derece doğaldır (Grant, 2011). Çünkü çoğulcu paradigma bir şeyi başarmanın birden fazla doğru yolu olduğu gibi; birden fazla doğru düşünme, hissetme, inanma ve davranma şeklinin olduğu; dahası hepsinin de değerli kabul edilmesi gerektiğini benimsemektedir (Shavlik, Judith, Touton ve Pearson, 1989). Dolayısıyla okul bireylere dünyayı anlamak için gerekli farklı bakış açılarının sunulacağı bir ortamı temsil etmektedir (Gay, 1990). Böyle bir ortamda bireyler eleştirel düşünme başta olmak üzere üst-düzey düşünme becerilerinin yanı sıra; hayal gücü, kavramsallaştırma, öz-eleştiri, fikirlerini gerekçelendirerek sunabilme, kendini özgürce ifade edebilme, reddetme ve muhalefet etme vb. yeteneklerini de geliştirebilirler (Alvarez, 2018; Motamed, Yarmohammadian ve Yousefy, 2013). Bu nedenle çoğulcu bir program bireylerin farklı hatta birbirleriyle çelişen yorum ve bakış açılarını anlayabilme, analiz edebilme ve mantıkı bir şekilde fikir üretebilmelerine olanak sağlamalıdır (Shevitz ve Wasserfall, 2006). Bununla birlikte, çoğulcu 
yaklaşıma göre söz konusu bu yetenek ve olanaklar sadece öğrencilere özgü olmamalı; öğretmenlerin de programda söz sahibi olabilmeleri için entelektüellik, akademik özgürlük, program süreçlerine katılım, programı eleştirme, sorgulama ve hatta değişim inisiyatifi vb. konularda desteklenmeleri gerekmektedir (Pinar, 2004). Çünkü öğrencilerde eleştiri kültürü oluşturmak isteyen bir öğretmene bu kültürün gerektirdiği bir çalışma ortamının sunulmaması tam anlamıyla bir çelişkidir (Pinar, 1999).

Okuldaki eleştiri kültürünün hayattaki karşılığı ise demokrasidir. Bu nedenle çoğulcu paradigma ile demokrasi birbirini tamamlayan olgulardır (Fallace, 2012). Dolayısıyla çoğulcu bir program demokratik bilince sahip vatandaşların yetiştirilmesine de katkı sağlamaktadır (McConnel, 2008). İnsan hakları, siyasi katılım, hukukun üstünlüğü, kısacası, demokratik kültür temeline dayalı olarak çoğulcu bir program sosyal sorunlara duyarlı, kendisini özgürce ifade edebilen ve siyasi kararlara etki etme yollarını arayan bireylerin yetiştirilmesini hedeflemektedir (Görmez, 2018). Ayrıca bireylerin ve toplumların karşııklı bağımlılıklarının giderek arttığı ve sınırı kaynakların giderek azaldığı bir dünyada çoğulcu programın öncelediği demokrasi kültürünün önemi de giderek daha çok belirginleşmektedir (Crowford ve Kirby, 2008). Zira iyi bir vatandaştan daha çok iyi bir insanı vurgulayan çoğulcu paradigma, demokrasinin bir yönetim şeklinden çok daha fazlası, birlikte yaşama kültürü olduğunu savunmaktadır (Chambers, 2010; Dewey, 1916).

Birlikte yaşama kültürünün önündeki en büyük engel nefret, önyargı ve ayrımcılıkla körüklenen ve bireylerin arasında oluşturulan suni duvarlardır (Louise, 1989). Bununla birlikte, söz konusu duvarlar ancak ben ve öteki'nin insani özelliklerinin ön plana çıkarılması ile aşılabilir (Fabretti, 2011). Bu özellikler ise eşitlik, sosyal adalet, karşılıklı saygı ve kabul vb. değerleri içerecek şekilde kavramsallaştırımalıdır (Grant, 2011). Dolayısıyla çoğulcu bir program paylaşım temelinde her bir bireyin ya da grubun eşit derecede değerli kabul edilmesini; dahası, her bir birey ya da grubun toplumun gelişimine yaptığı katkının takdir edilmesini savunmaktadır (Conyer,2011).

Çoğulcu paradigmaya ilişkin bireysel ya da toplumsal farklılıklar, düşünme becerileri, sosyal sorunlara ve değerler temelinde yapılan tanım ve açıklamalara bakıldığında; sadece demografik olarak çok kültürlü bir yapıya sahip toplumların değil, tüm ülkelerin çoğulcu bir programa ihtiyaç duyduğu çıkarımında bulunulabilir (Kaya ve Aydın, 2014). Dolayısıyla Türkiye de böyle bir ihtiyaca kayıtsız kalmamalıdır. Zira ülkenin demografik gerçeklerinin yanı sıra yasal zorunlulukları çoğulcu bir programı gerekli kılarken (Aydın, Aydoğdu ve Taş, 2010); demokratik bir toplum inşa etme hedefi böyle bir programı teşvik etmektedir (Gay, 2010).

Çoğulcu bir programa duyulan ihtiyaç aslında hâlihazırda uygulanmakta olan ve daha önce uygulanmış programların eleştirel bir bakış açısıyla incelenmesini, tartışımasını ve sorgulanmasını gerektirmektedir (Weinstein, 2004). Zira bu tür sorgulama hem mevcut hem de gelecekteki programları çoğulculuk yönüyle daha nitelikli hale getireceği gibi; programa ilişkin karar alıcılar için de referans kaynağı olacaktır (Applebee, 1996). Çoğulculuğun tanımı, kapsamı ve kuramsal temeli birlikte ele alındığında; eğitim programlarına yönelik yapılacak araştırmalar için ideal başlangıç noktalarından birisinin sosyal bilgiler dersi olduğu çıkarımında bulunulabilir (Solomon, 1988).

\section{Çoğulculuk ve Sosyal Bilgiler Öğretimi}

Insan ve sosyal hayata dair tüm konu, ilke ve genellemeleri içeren sosyal bilgiler (Sönmez, 2005) birey olarak kişinin gelişimi ve vatandaş olarak bireye kazandırılması beklenen özelliklerle ilgilenmektedir. Diğer bir ifade ile sosyal bilgiler bireylerin kişisel gelişimleri ile toplumun gelişimi arasındaki etkileşimi; bu etkileşimin sağlıklı bir zeminde yürütülmesini ve birey ile toplumun hedefleri arasında çıkması muhtemel çatışmaların çözümünü konu edinen disiplinler arası bir ders olarak nitelendirilebilir (Bilgili, 2015). Söz konusu bu etkileşim veya çatışmanın derecesi ise iyi insan ile iyi 
vatandaş hedeflerinin ne oranda birbirleriyle uyumlu hale getirilebildiklerine bağlı olarak değişmektedir (İnce, 2012).

Sosyal bilgiler dersinin esas itibariyle resmi ideolojinin arzu ettiği vatandaş profilini yetiştirme işlevi göz ardı edilmeyecek bir gerçek olsa da (Şen, 2019); özellikle son yıllarda farklııkların uyumu, küresel duyarlılık, geçmiş-bugün-gelecek ilişkisi, güncel olaylar ve toplumsal açıdan tartışmalı konular, insan hakları, barış eğitimi, çatışmaların çözümü vb. hedef ve içeriklerle daha insancıl bir tutumun bu dersin öğretimine yönelik hazırlanan programlara yansıtılmaya çalışıldığı görülmektedir (Akhan ve Yalçın, 2016). Ayrıca hukukun üstünlüğü, sivil toplum, kültürel ve etnik çeşitlilik, empati ve iş birliği, demokrasi gibi değerlerin benimsenmesi ve ön-plana çıkarılması çabalarının arttı̆̆ı gözlemlenmektedir (Öcal ve Yakar, 2015). Hem resmî ideolojinin arzu ettiği vatandaşları yetiştirme işleviyle (Keskin ve Keskin, 2015) hem de özellikle son yıllarda daha hümanisttik ve evrensel bir felsefeyle temellendirilmiş konu ve değerleri içermesi yönüyle (Ersoy, 2013) sosyal bilgiler dersi programlara yönelik çoğulcu bir inceleme, tartışma, eleştiri ya da sorgulama için ideal bir metin olarak değerlendirilebilir.

\section{Araştırmanın Amacı ve Önemi}

Eleştirel program teorisi, çoğulculuk ve sosyal bilgiler öğretimine ilişkin yapılan tanım, açıklama ve tartışmaların ışığında bu çalışmanın amacı, Cumhuriyet'in ilanından sonra sosyal bilgiler öğretimine yönelik uygulanan resmi eğitim programlarının (1924-2018) çoğulculuk bağlamında eleştirel bir bakış açısıyla incelenmesidir. Söz konusu bu amaç doğrultusunda araştırmada Türkiye'deki sosyal bilgiler öğretim programlarının; teorik ve ideolojik arka plan, birey ile bireysel ve toplumsal farklılıklar, düşünme becerileri, sosyal sorunlara duyarlıık, çoğulcu değerler boyutlarına ilişkin yaklaşımı sorgulanmış ve tartışılmıştır.

Söz konusu bu sorgulama programın tüm boyutlarıyla derinlemesine analiz edilmesini sağlayacaktır. Bu nedenle bu çalışma sonucunda elde edilen bulgularla hem eğitim programlarının etkililiğine ilişkin bir öneri sunulması hem de eğitimde ve program geliştirme alanında çoğulculuğa ilişkin tartışmalara derinlik kazandırııması amaçlanmaktadır.

Türkiye Cumhuriyeti'nin kuruluşundan bugüne (1924-2018) hazırlanan sosyal bilgiler öğretim programları araştırmanın kapsamındadır. Bu durumun temel nedeni eğitim programlarındaki düzenlemelerle ilgili çoğulculuk bağlamda problemlerin belirlenmesinin ve eğitim programlarındaki çoğulculuğa ilişkin problemlere çözüm önerilerinin geliştirilmesinin ancak programların tarihsel bir bağlamda ele alınması ile mümkün olabileceği varsayımıdır. Çünkü tarihsel temellere ilişkin yapılan çalışmalar araştırmacı ve eğitimcilere eğitim programlarında çoğulculuğun ne kadar yer tuttuğuna ilişkin farklı ve geniş bakış açıları kazandırabilir (Özmantar, Ağaç ve İlgün, 2017). Zira Oliva’ya (2009) göre program sadece hazırlandığı ve uygulandığı dönemin şartlarını yansıtmakla kalmaz; aynı zamanda program döneminin bir ürünüdür. Dolayısıyla programı hazırlandığı ve uygulandığı dönemin şartlarından bağımsız analiz etmek programı asıl bağlamından uzaklaştırmak anlamına gelir ki; böyle bir analizin yüzeysel kalacağı açıktır. Programlar, ayrıca hem birey hem de ulus olarak geçmişin izlerini taşımaktadır. Çünkü içinde bulunulan an geçmişin üzerine kurulur ve benzer prensiplerle çalışmaktadır. Diğer bir deyişle geçmiş hem geleceği hem de günümüzü şekillendirmektedir. Pinar (2004; s.20), bu durumu şu şekilde ifade etmektedir;

"Program geçmişle ilgili hatırlamayı istediğimiz, günümüzle ilgili inanmayı seçtiğimiz ve geleceğe ilişkin umut etmeye karar verdiklerimizin yansımasıdır."

Bu nedenle Türkiye Cumhuriyeti'nin kuruluşundan bugüne (1924-2018) hazırlanan sosyal bilgiler öğretim programların incelenmesi her bir programın nasıl bir geçmiş hatırlatmayı istediği, nasıl bir 
mevcut duruma inanmayı seçtiği ve nasıl bir gelecek hayal ettiğine ilişkin hem eğitimcilere hem program araştırmacılarına hem de Türkiye'nin toplumsal tarihine ilgi duyanlara önemli katkı sağlayacaktır. Ayrıca böyle bir analiz bütün olarak Türkiye'deki programların geçmişi, hâlihazırdaki durumu ve geleceğine ilişkin önemli ipuçları sunacaktır.

Bireylerin giderek farklılaştığı ve birbirinden uzaklaştığı öteki'nin düşman olarak görülmeye başlandığı, empati özelliğinin kaybolduğu bir iklimde (Helpern ve Weinstein, 2004) çoğulculukla ilgili farklı bilme ve öğrenme yollarının doğal olduğunun ve farklılıklara saygının vurgulandığı araştırmaların sayısının artması toplumsal huzur ve refah açısından oldukça önemlidir. Çünkü Gay'e (2010) göre, göç ve göçmen sayısı arttıkça insanların farklılıklara ve farklı dilleri konuşanlara karşı hoşgörüsü azalmaktadır. Bu nedenle göç, sağlık, savaş, ekonomik durum vb. nedenlerden dolayı hem ulusal hem de uluslararası düzeyde farklı özgeçmişlere sahip bireylerin bir araya gelmesi, bu insanların bir arada yaşayabilmesine ilişkin çözüm önerilerinin araştırılması gerekliliğini doğurmuştur. Bu çalışma ile bu tür çabalara katkı sağlanacağı düşünülmektedir.

Oliva'ya (2009) göre insanlar programı değiştirdiği gibi program da insanları değiştirmeyi hedefler. Programın nasıl bir insan hedeflediğini analiz etmek programın arkasındaki felsefeyi ve siyasi, sosyal, dini vb. temelleri de ortaya çıkaracaktır. Bu nedenle çalışmanın sonunda elde edilen bulgular; öğrenciler, öğretmenler, veliler ve eğitimciler dâhil olmak üzere eğitimin tüm paydaşlarına program hazırlayan resmi otoritenin çoğulculuğa ilişkin bakış açısıyla ilgili çıkarımlar yapma olanağı verecektir.

Araştırma konusu olarak sosyal bilgiler öğretiminin seçiminde bu dersin kapsamının çoğulcu paradigmanın temel varsayımları ile olan yakın ilişkisinin yanı sıra (Hicks, 2003; McConnell, 2008); Dewey'in (1922); özellikle tarih, coğrafya ve sosyal bilgiler dersleri entelektüel olarak daha dürüst olması ve öğrencileri toplumsal sorunları tartışmaya teşvik etmesi gerektiğine ilişkin görüşü temel alınmıştır. Ayrıca araştırmada ilkokul ve ortaokul (ilköğretim) kademesinden bir dersin programının incelenmesinin altında yatan gerekçe ise bu kademenin bilgi, beceri ve kazanım yönüyle bireylerin hayatlarında daha derin etkiler bırakmasıdır (Merey, 2015). Dahası araştırma kapsamının Cumhuriyet'in ilanından sonra (1924-2018) uygulanan programlar ile çerçevelendirilmesi resmi ideolojiye ilişkin bütüncül bir sorgulama yapabilme amacından kaynaklanmaktadır.

Araştırma konusu ve kapsamının yanı sıra; araştırmanın özgünlüğü ve orijinalliğine yönelik YÖK Tez Merkezi, ULAKBIM, EBSCO, ERIC, Google Akademik ve Proquest gibi veri tabanları üzerinden "çoğulcu program", "çoğulcu eğitim", "eğitim programlarında çoğulculuk", "Pluralistic curriculum", "pluralistic education", "pluralism in curriculum" vb. anahtar kelimeler girilerek yapılan literatür taramasının sonucunda bu konuda yapılacak yeni çalışmalara ihtiyaç duyulduğu çıkarımında bulunulmuştur.

\section{Yöntem}

Türkiye'de Cumhuriyet'in ilanından sonra uygulanan sosyal bilgiler öğretimine yönelik programların çoğulculuk perspektifinden incelenmesinin amaçlandığı bu nitel araştırma bütüncül çoklu durum çalışması deseni kullanılarak tasarlanmıştır. Olay, olgu, bağlam, program, grup ya da birbirleriyle ilişkili sistemlerin derinlemesine incelendiği durum çalışmasının bir deseni olan bütüncül çoklu durum çalışması birden fazla durumun kendi içinde analiz edilmesini ve birbirleriyle karşılaşmasını nitelemektedir (Gustafsson, 2017; Yıldırım ve Şimşek, 2016). Bu doğrultuda araştırmada her bir öğretim programı kendi içinde sınırları belirli bir durum olarak ele alınmış; daha sonra birbirleriyle karşılaştııılmaları yapılarak programların çoğulcu paradigma bağlamında bütüncül 
bir analizine ulaşılmaya çalışıımıştır. Özellikle son yıllarda eğitim programlarını da durum olarak niteleyen araştırmaların artması (Akar, 2016) bu çalışma için de bilimsel bir dayanak oluşturmuştur.

\section{Veri Seti}

Araştırmanın amacı, konusu ve kapsamı göz önüne alındığında; bu çalışmada veri seti nitel araştırmaların doğasına uygun bir şekilde amaçlı örneklem yöntemi kullanılarak seçilmiştir. Frankel, Wallen ve Hyun'un (2012) açıklamalarına uygun olarak araştırmanın veri setini 1924-2018 tarihleri arasında geliştirilen eğitim programlarından sosyal bilgiler öğretimi kapsamındaki derslerin programları oluşturmaktadır. Zira Cumhuriyet ilan edildikten sonra hazırlanan ilk program 1924 Programı iken; en güncel ve halen uygulanmakta olan program 2018 Programı'dır. Dolayısıyla yapılan literatür taraması sonucunda 1924, 1926, 1936, 1948, 1962, 1968, 1990, 1998, 2005, 2015 ve 2018 yıllarında sosyal bilgiler adıyla ya da farklı isimlerle adlandııımalarına rağmen sosyal bilgiler öğretimi kapsamına giren derslere yönelik öğretim programları bulunduğu sonucuna ulaşılmıştır (Akpınar ve Kaymakçı, 2012; Alp, 2017; Bilgili, 2015; Kan, 2010; Safran, 2011; Sönmez, 2005; Türkoğlu ve Sarı, 2006). Bu doğrultuda eğitim programlarının geliştirildiği yıllara göre araştırma kapsamında incelenen derslerin öğretim programları Tablo 1'de gösterilmiştir.

Tablo 1.

Çalışma kapsamında incelenen programlar

\begin{tabular}{|c|c|c|}
\hline & Program & Öğretim Programları İncelenen Dersler \\
\hline İkincil kaynak & 1924 Illk Mektep Programı & $\begin{array}{l}\text { Tarih } \\
\text { Coğrafya } \\
\text { Musabahat-ı Ahlakiye ve Malumat-ı Vataniye }\end{array}$ \\
\hline Birincil kaynak & 1926 İlk Mektep Programı & $\begin{array}{l}\text { Tarih } \\
\text { Coğrafya } \\
\text { Yurt Bilgisi }\end{array}$ \\
\hline Birincil kaynak & 1936 İlkokul Programı & $\begin{array}{l}\text { Tarih } \\
\text { Coğrafya } \\
\text { Yurt Bilgisi }\end{array}$ \\
\hline Birincil kaynak & 1948 İlkokul Programı & $\begin{array}{l}\text { Tarih } \\
\text { Coğrafya } \\
\text { Yurttaşlık Bilgisi }\end{array}$ \\
\hline Birincil kaynak & 1962 İlkokul Program Taslağı & Toplum ve Ülke İncelemeleri \\
\hline Birincil kaynak & 1968 ilkokul Programı & Sosyal Bilgiler \\
\hline Birincil kaynak & 1990 Sosyal Bilgiler Öğretim Programı & Sosyal Bilgiler \\
\hline Birincil kaynak & 1998 Sosyal Bilgiler Öğretim Programı & Sosyal Bilgiler \\
\hline Birincil kaynak & 2005 Sosyal Bilgiler Öğretim Programı & Sosyal Bilgiler \\
\hline Birincil kaynak & 2015 Sosyal Bilgiler Öğretim Programı & Sosyal Bilgiler \\
\hline Birincil kaynak & 2018 Sosyal Bilgiler Öğretim Programı & Sosyal Bilgiler \\
\hline
\end{tabular}




\section{Verilerin Tanımlanması}

Araştırmanın veri setini 1924-2018 yılları arasında sosyal bilgiler öğretimine yönelik hazırlanan programlar oluşturduğu için öğretim programları üzerinden geçmişe dönük görüşme/gözlem olanağının bulunmaması ve temel olarak farklı zamanlarda yayımlanmış yazılı materyallerin analizine odaklanılması nedenlerinden dolayı (Cresswell, 2013) verilerin toplanmasında doküman incelenmesinden yararlanılmıştır. Bununla birlikte her bir programın uygulandığı dönemde veya döneme ilişkin eğitimci, politikacı, araştırmacı ve uzmanların görüş/gözlemlerini yansıtan dokümanlardan da yararlanılarak bu eksiklik giderilmeye çalışılmıştır.

Verilerin toplanması sürecinde araştırmanın veri setini oluşturan ve Tablo 1'de gösterilen eğitim programlarının tamamına ulaşılmıştır. Ancak Türkiye'de programlar Harf Devrimi nedeniyle 1928'den sonra Latin harfleriyle yazılmaya başlandığı için 1924 İlkokul Programı́nın Alp (2017) tarafından Latin harfleriyle yeniden yazılan ve Köprülü (2018) tarafından orijinallik kontrolü yaptırılan baskısı ile 1926 ilkokul Programı'nın 1930'da yeni harflerle tekrardan yazılan versiyonu kullanılmıştır. Diğer programlara ise Milli Eğitim Bakanlığı'nın arşivi ile Talim ve Terbiye Kurulu'nun internet sayfasından ulaşılmıştır.

\section{Verilerin Analizi}

Bu çalışmanın veri setinin oluşturan eğitim programlarının incelenmesinde betimsel analiz yöntemi kullanılmıştır. Ayrıca programlara ek olarak araştırma konusuyla ilgili bilimsel makaleler, raporlar, hükümet programları, politikacıların konuşmaları ve anılarından yararlanılmıștır. Analiz sürecinde birbirleriyle ilişkili ve birbirini tamamlayan iki yol izlenmiştir. Öncelikle ulaşılan programlar ve diğer kaynaklar analiz sürecinin güvenilir bir şekilde yürütülebilmesi için tek tek okunmuştur. Hatta hem programların gelişim sürecinin daha iyi anlaşılabilmesi hem de bütüncül ve derinlemesine bir analizin yapılabilmesi için programlar eskiden yeniye doğru okunmuştur. Programlara ek olarak çoğulculuk, eleştirel program teorisi ve sosyal bilgiler öğretimine yönelik literatür taranmıştır. Ön okumalar sonucunda "Programın Çoğulcu Bakış Açısından Eleştirel Analizi Soruları" ile çoğulculuğun boyutları ve bu boyutlara ilişkin temalar-kodlar belirlenmiştir. Hem sorular hem de boyutlar-temalarkodlar analiz sürecinin başlangıcını oluşturmuştur. Sonrasında nitel yaklaşımın doğasına uygun olarak tekrar tekrar gözden geçirme, ekleme, çıkarama, değiştirme gibi süreçlerle yeniden düzenlemeler yapılmıştır. Analiz soruları ile çoğulculuğun boyutlarına ilişkin tema ve kodlara son hali verildikten sonra analiz süreci aşağıda belirtilen alt başlıklara ayrılarak yürütülmüştür;

\footnotetext{
$\checkmark$ Programın Teorik ve İdeolojik Arka Planı

$\checkmark$ Birey ile Bireysel ve toplumsal Farklılıklar

$\checkmark$ Düşünme Becerileri

$\checkmark$ Sosyal Sorunlara Duyarlılık

$\checkmark$ Çoğulcu Değerler
}

Bu başıklar aynı zamanda literatür taraması ile belirlenen çoğulculuğun boyutlarıdır ve araştırmanın da alt amaçlarını oluşturmaktadır. Her bir boyuta ilişkin belirlenen tema ve kodlar ile eleştirel analiz soruları ışığında programlar kelime, cümle ve paragraf seviyesinde tek tek incelenmiştir. Raporlama sürecinde ise hem bulguların yorumlanmasında hem de sonuçların tartışımasında aynı boyutlar alt başlıklar olarak kullanılmıştır.

\section{Geçerlilik ve Güvenirlik}

Frankel vd.'ne göre (2012) göre nitel araştırmalarda geçerliliğin sağlanmasının temel şartları uyum, anlamlılık ve kullanışlılıktır. Öncelikle uyum araştırmada elde edilen veriler ile yapılan 
çıkarımlar arasındaki tutarıılığı ifade etmektedir. Bu çalışmada uyum şartını sağlamak için Frankel vd.'nin (2012) önerdiği şekilde eğitim programları alanında uzman dışsal bir değerlendirmeciden genel olarak bulgular ile çıkarımlar özel olarak ise çoğulculuğa ilişkin belirlenen boyutlar ile bu boyutlara ilişkin belirlenen tema ve kodların ne oranda uyumlu olduğuna dair görüşleri istenmiştir. Söz konusu uzmanın görüşlerinden yararlanılarak gerekli değişiklikler yapılmış ve ulaşılan çıkarımlar da yeniden düzenlenmiştir.

Araştırmanın geçerliliğin ikinci şartı çıkarımların anlamlılığıdır (Frankel vd., 2012;s. 458). Bu doğrultuda araştırmanın sadece tarihsel bir analiz olarak yapılandırılmasından özellikle kaçınıımış; yapılan analiz bugüne yansıyan yönleri ile ele alınmaya çalışılmıştır. Ayrıca bulguların tartışılmasında her bir programın geliştirildiği ve uygulandığı bağlam o dönemle sınırlandırılmamış; sürekli olarak diğer programların bağlamları ile ilişkilendirilerek çıkarımların geçmişten-bugüne sürekliliğinin sağlanması amaçlanmıştır. Böylece bugünün eğitimi ve eğitim programlarının eksiklik ve problemleri ile ilgili çıkarımların daha anlamlı hale gelmesi hedeflenmiştir. Dahası öneriler eğitimin etkilediği ve eğitimden etkilenen tüm bireylerle (öğrenci, öğretmen, politikacı, veli, program uzmanı, akademisyen, eğitim araştırmacıları vb.) ilişkilendirilerek tartışılmış; böylece herkes için anlamlı çıkarımlara ulaşılması arzu edilmiştir.

Araştırmanın son geçerlilik şartı kullanışıııktır. Bu şartı sağlamak amacıyla araştırma sonucunda ortaya çıkan önerilerin neden-sonuç ilişkilerine dikkat çekilmiş; özel olarak öğretmenlere, eğitim araştırmacılarına ve politika geliştiricilere yönelik önerilerde bulunulmuştur. Böylece araştırma sonuçlarının hayata transfer edilebilirliği artırılmaya çalışılmıştır (Crouch ve McKenzie, 2006).

Nitel araştırmalarda çıkarımların zaman, mekan ve farklı şartlardaki tutarlıığını ifade eden güvenilirlik (Meriam, 2013) aynı araştırmacının iki farklı tarihteki kodlamaları ya da farklı iki araştırmacının kodlamaları arasındaki uyuma bakarak sağlanabilir (Miles ve Huberman, 1994). Bu araştırmada her iki yönteme de başvurulmuştur. Öncelikle iki farkı araştırmacı tarafından yapılan kodlamalar için çalışmanın başından itibaren araştırma konusu hakkında bilgili, araştırma sürecine aşina ve kuramsal olarak araştırmanın aşamalarını gözlemleme olanı olan uzmanlar seçilmiştir. Puanlayıcılar arası uyum Miles ve Huberman (1994) tarafından geliştirilen uyum yüzdesinin hesaplanmasına ilişkin formül kullanılarak yapılan hesaplamada iki araştırmacının kodlamaları arasında \%93'lük bir uyum bulunmuştur. Yine aynı uyum yüzdesinden faydalanılarak araştırmacının iki farklı tarihteki kodlamaları arasındaki uyum yüzdesi \%92 şeklinde hesaplanmıştır. Nitel araştırmalarda araştırmacının süreç boyunca hem araştırmasını hem de araştırmasına ilişkin zihinsel algılamalarını sürekli yeniden yapılandırıldı̆̆ı tespiti (Cresswell, 2013) göz önünde bulundurulduğunda; araştırmacı tarafından iki farklı tarihte yapılan kodlamalar arasındaki uyum yüzdesinin söz konusu bu yeniden yapılandırmayı yansıttığı çıkarımında bulunulabilir.

\section{Bulgular}

Araştırmada verilerin analizi sonucunda elde edilen bulgular aşağıdaki başlıklar altında sunulmuştur.

\section{Çoğulculuk Bağlamında Sosyal Bilgiler Öğretiminin Teorik ve İdeolojik Arka Planı (1924-2018)}

Cumhuriyetin ilk programı olan 1924 ilkokul Programı ve bu programdaki sosyal bilgiler öğretimine yönelik derslerin ideolojik arka planını Osmanlı'dan Cumhuriyet'e geçişte yaşanılan değişikliklerin bir gereği olarak yeni devlete uygun toplum yaratma amacı şekillendirmiştir (Ertuğrul, 2000). Dolayısıyla çok uluslu Osmanlı'dan sonra kurulan tek uluslu devlette sosyal bilgiler öğretimi 
yeni rejimi benimsetme (Caymaz, 2008), laik/seküler bir Türk kimliği oluşturma (Ince, 2012) ve devletin siyasi işleyişi ile ilgili bilgileri aktarma işlevi görmüştür (Polat, 2011). Tebaadan vatandaşa geçişte bir tür zihinsel devrim hedefini taşıyan programın yeni kurulan ulus devletin gerektirdiği homojen bir toplum oluşturulması amacına hizmet etmiştir(Alp, 2017).

Pragmatizm ve John Dewey'in görüşlerinin o dönem Türkiye'sindeki savunucularından olan M. Emin Erişilgil ve Avni Başman'ın öncülüğünde hazırlanan 1926 ilkokul Programı́nda (Hesapçıoğlu, 2010) sosyal bilgiler öğretimi bireyleri 1924-1934 arasında yapılması planlanan devrimlere hazırlamak (Çayır, 2015) ve bireylerin devrimleri benimsemelerini sağlamak (Gülbahar, 2006) hedefleri doğrultusunda yapılandırılmıştır. Dolayısıyla pragmatist eğitimciler tarafından idealist ve realist beklentilerle hazırlanan programdaki teorik ve ideolojik ikilem (Çetin, 2000) programın uygulamadaki etkinliğini olumsuz yönde etkilemiştir (Sakaoğlu, 2018).

Rejimin eğitimden beklentilerini en iyi yansıtan program olarak tanımlanabilecek 1936 illkokul Programı'nda (Fer, 2010) sosyal bilgiler öğretimi ile devrimlere yürekten bağlı (Tazebay, 2000) ve onları korumak için her türlü fedakarlığı yapabilecek (Ünal ve Ünal, 2010) bireylerin yetiştirilmesi hedeflenmiştir (Milli Eğitim Bakanlığı, 1936). İktidardaki Cumhuriyet Halk Partisi'nin parti programı niteliğinde olan programda (Alp,2017) oldukça yoğun bir siyasi etkinin (Türkoğlu ve Sarı, 2006) ve katı sayılabilecek bir milliyetçilik anlayışının izlerini görmek mümkündür (Kabadere, 2010).

M. Kemal Atatürk'ün vefatının ardından ülkedeki siyasi değişiklikler ve bu değişikliklerin toplumsal yansımaları (Güler, 2004) ile II. Dünya Savaşı'nın ekonomik anlamda olumsuz etkilerinin (Sakaoğlu, 2018) gölgesinde hazırlanan 1948 i̇lkokul Programı'nda sosyal bilgiler öğretimi, daha önceki programların ideolojik amaçlarını kapsamakla birlikte (Akpınar ve Kaymakçı, 2012) çok partili sistemin ilkel heyecanı (Kabadere, 2010) ve olgunlaşmamış bir demokrasi anlayışı (Binbaşıoğlu, 2005) etrafında tasarlanmıştır.

1962 Illkokul Program Taslağı 1950lerin başlangıcından itibaren programları daha demokratikleştirme çabalarının bir sonucu olarak hazırlanmıştır. Programın hazırlanış sürecinde Amerikalı uzmanların görüşlerinden faydalanılması (Wofford, 1952); programın deneme okullarında yürütülen çalışmaların bulgularından yararlanılarak geliştirilmesi (Green ve Karagöz, 1965) vb. durumlar bilimsellik açısından programı önceki programlardan olumlu anlamda ayırmaktadır(Aktan, 2006). Programın ideolojik arka planında ise liberalizm (Bayri, 2008), çok partili hayata geçiş süreci (Üstel, 2011), ülkeyi neredeyse çeyrek asırdır yöneten partinin iktidarı kaybetmesi (Güler, 2004), daha çok özgürlük vaadi ile yönetimi devralan Demokrat Parti'nin giderek otoriterleşen popülist söylemi (Sakaoğlu, 2018), 1960 ihtilali (Güven, 2000), Yeni Anayasa (Keyman ve Kanci, 2011) vb. olaylar yatmaktadır. Bu nedenle o dönem sosyal bilgiler öğretimine yönelik hazırlana ders kitaplarında Demokrat Parti'nin ağır bir eleştirisine ve 27 Mayıs darbesinin bir ihtilal olarak pozitif temsiline yer verilmiştir (Şen, 2019).

Sosyal bilgiler öğretiminin ilk defa kendi adıyla yer alan bir ders aracılığıyla yürütüldüğü 1968 illkokul Programı́nda (Türkoğlu, 2010) insan hakları ve demokrasi olguları önceki programlara oranla daha güçlü bir şekilde vurgulanmıştır(Bilgili, 2015). Programın ideolojik açıdan en büyük çelişkisi ise oldukça özgürlükçü bir anlayışla hazırlanmasına rağmen (Tural, 2006); ülkedeki sosyal ve siyasal yapıların söz konusu bu özgürlükçü anlayışın gerekliliklerini karşılayacak yeterlilikte olmaması nedeniyle uygulamada istenilen etkililiği gösterememesidir (Güven, 2000).

1968 İlkokul Programı'ndaki devrim kelimelerinin tamamının inkılap kelimesine dönüştürülmesi haricinde metin olarak neredeyse hiçbir değişiklik yapılmadan uygulamaya konan 1990 Sosyal Bilgiler Dersi Öğretim Programı 12 Eylül darbesinin zihinsel etkisi altında hazırlanmıştır (Kaplan, 2002). Atatürkçülük ya da Atatürk milliyetçiliği temelinde kavramsallaştırılan resmi ideolojiye ulusal kimliğin ayrılmaz bir parçası olarak dinin de etkilenmesi söz konusu bu zihinsel etkiyi 
yansıtmaktadır (Çayır, 2015). Bu yönüyle program ideolojik kutuplaşmaları yok etmek için devlete bağlılık vurgusuyla adeta zorunlu bir konsensüs (uzlaşma) yaratarak resmî ideolojiyi AtatürkçülükTürkçülük-İslamiyet-Laiklik sentezi şeklinde sunan politik stratejiden izler taşımaktadır (Şen, 2019).

Zorunlu eğitimin kesintisiz 8 yıla çıkarılması kararı ile uyumlu olarak geliştirilen 1998 Sosyal Bilgiler Dersi Öğretim Programı o dönem Türkiye'sinde sadece eğitime değil neredeyse tüm yaşam alanlarına egemen olan militarist bakış açısıyla hazırlanmıştır (Sakallıoğlu ve Çınar, 2003). Dolayısıyla programın ideolojik arka planını milliyetçiliği esas alan aşırı korumacı militarist bir yaklaşım (Davison, 2003) ile tekçi sosyal kimlik (Çayır, 2009) ve homojen toplum yapısı (Keyman ve Kanci, 2011) hedefleri oluşturmaktadır.

Yapılandırmacılık, tematik yaklaşım ve disiplinler arası eğitim gibi eğitimsel açıdan bir dizi yeni perspektifle hazırlandığı savunulan 2005 Sosyal Bilgiler Dersi Öğretim Programı (MEB, 2005) Avrupa Birliği ile kurulan yakın yakın ilişkilerin de etkisiyle daha özgürlükçü bir anlayış sunma iddiasıyla şekillenmiştir (Şen, 2019). Bununla birlikte programın hazırlanmasındaki en önemli ideolojik motivasyonun ülke siyasetindeki köklü sayılabilecek değişiklikler olduğu (Yelken ve Büyükcan, 2015) görüşü göz önüne alındığında; programla ilgili esas tartışmanın Toland'ın (1998) ifadesiyle ülkedeki egemen siyasi geleneğe uygun yeni kimlik yaratma konusunda yaşandığı çıkarımında bulunulabilir (Korkmaz, 2017).

2005'teki programın büyük oranda aynısı olarak nitelendirilebilecek 2015 Sosyal Bilgiler Dersi Öğretim Programı bir tür güncelleme olarak tanımlanabilir (Çoban ve Akşit, 2018). Hem teorik hem de ideolojik olarak 2005'teki programla başlayan anlayış ülkedeki özgürlüklerin aşağı yönlü bir eğilim gösterdiği eleştirilerine rağmen (Özbudun, 2014) 2015 Sosyal Bilgiler Dersi Öğretim Programı'na da yansıtılmıştır.

Ülkenin yaşadığı en sarsıcı olaylardan biri sayılabilecek başarısız darbe girişiminin ardından uygulama konan 2018 Sosyal Bilgiler Dersi Öğretim Programı ulusal güvenlik endişelerinin ve milliyetçi söylemlerin arttığı bir ortamda geliştirilmiştir (Şen, 2019). 2005 ve 2015'teki programlarla hem büyük oranda aynı içeriğe sahip olmasına hem de aynı ideolojik motivasyonla hazırlanmasına karşın; 2018 Sosyal Bilgiler Dersi Öğretim Programı'nda Atatürk ile ilgili kazanım sayısının azaltılması (Kaplan, 2017), ilk defa "cihat" kavramına yer verilmesi (MEB, 2018), Avrupa devletleri ile insan hakları ihlallerine ilişkin yaşanan sorunlar (Aktürk, 2018) vb. tartışmaların izlerini görmek mümkündür.

Cumhuriyet'in ilanından itibaren sosyal bilgiler öğretimine yönelik hazırlanan programların "teorik ve ideolojik arka planı" Tablo 2'de özetlenmiştir

Tablo 2.

Programların teorik ve ideolojik arka planı

\begin{tabular}{|c|c|}
\hline İncelenen Program & Programların "Teorik ve İdeolojik Arka Plan"ına İlişkin Alıntılar \\
\hline $\begin{array}{l}1924 \text { ilkokul } \\
\text { Programı }\end{array}$ & $\begin{array}{l}\text { "Türkiye Cumhuriyetinin ne gibi fedakârlıklar pahasına teessüs ettiğini, hakiki } \\
\text { dostlarını ve düşmanlarını öğrenmeleri elzemdir" (MEB, 1924) }\end{array}$ \\
\hline $\begin{array}{l}1926 \text { illkokul } \\
\text { Programı }\end{array}$ & $\begin{array}{l}\text { "Cumhuriyet eğitiminin en önemli görevlerinden birisi memleket olaylarının } \\
\text { ideolojisini anlayacak, anlatacak, nesilden nesile yaşatacak fert ve kurumlar } \\
\text { yaratmaktır" (M. Kemal Atatürk) }\end{array}$ \\
\hline $\begin{array}{l}1936 \text { illkokul } \\
\text { Programı }\end{array}$ & $\begin{array}{l}\text { "illkokulun eğitim yolu ile Türk milletinin ortak malı haline getireceği yeni kıymetler } \\
\text { rejimin kültür hakkındaki esas düsturlarıdır ki; onlar da Cumhuriyet Halk Partisi } \\
\text { programının ulusal eğitim kısmında saptanmıştır" (MEB, 1936) }\end{array}$ \\
\hline $\begin{array}{l}1948 \text { illkokul } \\
\text { Programı }\end{array}$ & $\begin{array}{l}\text { "Yurdumuzun medeniyet ve refah yolunda ilerlemişini halk iradesine dayanan } \\
\text { idarenin devamında görüyoruz. Bunun için her derecedeki okullarımızda demokratik }\end{array}$ \\
\hline
\end{tabular}


1962 ilkokul Programı Taslağı

1968 ilkokul Programı

1990 Sosyal Bilgiler Dersi Öğretim Programı 1998 Sosyal Bilgiler Dersi Öğretim Programı

2005 Sosyal Bilgiler Dersi Öğretim Programı

2015 Sosyal Bilgiler Dersi Öğretim Programı

2018 Sosyal Bilgiler Dersi Öğretim Programı terbiyenin yerleşmesine ehemmiyet vereceğiz" (Tahsin Banguoğlu, 1946'dan akt. Kabadere, 2010)

"Demokrasinin karakteristik özelliği özgürlüktür; karakteristik erdemi hoşgörüdür; karakteristik ilkesi düşünme ve tartışma özgürlüğüdür" (Pars, 1950'den akt. Binbaşıŏlu, 2005)

"Milli eğitim ülkümüz milletimizi hür düşüncenin, sosyal zihniyet ile demokratik düzenin hâkim olduğu bir anlayış içinde çağdaş uygarlığın yapıcı, yaratıcı ve seçkin bir ortağı haline getirmektedir" (MEB)

"Gerekirse çoğunluğun yararına kişisel fedakârlıkta bulunabilir" (MEB, 1990)

"Güçlü Türkiye'nin arzulanmayışı..." (MEB, 1990)

"Öğrencilere çoğulcu demokratik rejimin başka rejimlerden üstünlüğü tarihten örnekler verilerek kavratılır" (MEB, 1998)

“TSK'nın önemi ve Türkiye Cumhuriyeti'nin varlığının teminatı olduğunu söyleme" (MEB, 1998)

"Program yapılandırmacı anlayışla hazırlanmıştır" (MEB, 2005)

"Bilgi iktidarın aracıdır, iktidarı beslemek ve güçlendirmek için işler. Bu nedenle her iktidar arayışıyla birlikte bilginin araçsallığı da artar" (Foucoult, 1980)

"Sosyal bilgiler etkin ve üreten bireyler yetiştirmek, öğrencilerin insan ilişkilerini ve vatandaşlık yeterliliklerini geliştirmeyi amaçlayan bir derstir" (MEB, 2015)

"Türk eğitim sistemi çok az öğrenciyi iyi eğitmekte ama öğrencilerin çoğunu başarısız kılmaktadır" (Dünya Bankası Eğitim Raporu, 2010'dan akt. Sarıer, 2010)

"Gaza ve cihat anlayışı üzerinde durulur" (MEB, 2018)

"Coğrafi Keşifler, Rönesans, Aydınlanma Çağı, Reform, Fransız ihtilali, Sanayi Inkılabı, Sömürgecilik ve bunların neden olduğu karmaşa ile insan hakları ihlallerine değinilir" (MEB, 2018)

\section{Çoğulculuk Bağlamında Sosyal Bilgiler Öğretiminde "Birey ile Bireysel ve Toplumsal Farklılıklar" (1924-2018)}

1924 İlkokul Programı́nda sosyal bilgiler öğretimine ilişkin derslerde bireylerin kişilik ve karakter gelişimlerine kısmi bir vurgu yapılsa da (Binbaşıoğlu, 2005); bu durum bireyselliğin ön plana çıkarılmasından ziyade (Hesapçıoğlu, 2009) yeni devletin arzu ettiği vatandaş tipini yetiştirme stratejisi olarak görülmelidir (Cicioğlu, 2010). Ayrıca söz konusu derslerin programlarında kültürel farklılıklara yapılan atıflar yetersiz kalırken (Çetin, 2003); etnik ve kimlik farklılıklarına ilişkin ise herhangi bir içerik tespit edilememiştir (Üstel, 2011). Kadınlara yönelik ise programda yer alan Nakış, Biçki, Dikiş ve Ev idaresi dersleri aracılığıyla cinsiyet ayrımcılığını çağrıştıran sosyal algının pekiştirilmesine neden olunmuştur (Dedeoğlu, 2009).

Sosyal bilgiler öğretimine yönelik 1926 illkokul Programı'nda yer alan derslerde pragmatist anlayışın etkileri bireye, bireyin biricikliği ile ilgi ve ihtiyaçlarına yapılan atıflarla kendini göstermektedir (MEB, 1926). Bununla birlikte programda merkeziyetçi bir modelin egemen olduğu toplumcu bir politikanın benimsenmesi (Kabadere, 2010) bireyselliğin yerini toplumun çıkarlarına bırakmasına sebep olmuştur (Kahraman, 2007). Programda kültürel ve etnisiteye yönelik farklııkları vurgulayan oldukça az sayıdaki çoğulcu öge ise homojen toplum hedefinin gölgesinde kalmıştır(Çetin, 2003). Ayrıca kadınlar temel görevleri annelik veya iyi bir eş olmak olan ikinci sınıf vatandaşlar olarak resmedilmiş (Oğuz, 2007); dolayısıyla, cinsiyet rollerine ilişkin yanlı ve önyargılı tutum sürdürülmüştür (Esen, 2007).

1936 yılındaki programda sosyal bilgiler öğretimi bireylere rejimin sadık ve fedakâr bir unsuru olarak devrimleri muhafaza etme görevi verdiği için $(M E B, 1936)$ bireyin tüm benliğini ortak çıkarlar uğruna feda etmesi yüceltilmiştir (MEB,1936). Programda pragmatizmin izlerine rastlansa da 
(Binbaşıoğlu, 2005); 1936 illkokul Programı 1926'daki programa oranla daha az bireysel (Alp, 2017), daha az esnek (Fer, 2010) ve daha çok merkeziyetçidir (Kabadere, 2010). Programda etnisite ve kimlik farklılıklarına ilişkin herhangi bir çoğulcu öge tespit edilemezken; kültür ve yaşayış tarzı farklılıkları da yüzeysel bir şekilde ele alınmıştır (Çetin, 2003).

Sosyal bilgiler öğretimi daha önceki programlarda olduğu gibi 1948 illkokul Programı́nda da topluluk içinde birey anlayışıyla şekillenmiştir (Polat, 2011). Bu durum programda bireye yapılan atıfları gölgelerken (Üstel, 2011) programın Dewey'in (1996) ifadesiyle sosyal kontrol yoluyla bireysel etkinlikleri domine etmeyi amaçladığına ilişkin bir izlenimin oluşmasına sebep olmuştur. Ayrıca etnisite farklılıklarına yönelik sessizlik 1948'deki programda da sürdürülmüş (Keyman ve Kanci, 2011); cinsiyetçi bakış açısı da terk edilmemiştir (Karakuş, Mutlu ve Coşkun, 2018).

1950'den sonra ülkeye gelen yabancı uzmanların ısrarla üzerinde durduğu daha bireysel ve demokratik program anlayışı (Keller, 1954; Wofford, 1952) 1961 Anayasası'nın özgürlükçü yaklaşımı (Tural, 2006) ile birleşince 1962 ilkkokul Programı Taslağı'nda sosyal bilgiler öğretimi çoğulculuk açısından daha olumlu bir metin haline gelmiştir (Carlson ve Kanci, 2016). Bireysel farklılıkların yanı sıra öğrencilerin programın uygulamadaki planlanmasına etkin katılımının önerilmesi (MEB, 1962) programın demokratik perspektifini güçlendirmektedir. Ayrıca önceki programlardan farklı olarak insan hakları, ırksal farklılıklar, dini tercihler, cinsiyet farklılıkları vb. çoğulcu olarak nitelendirilebilecek kavramlara ilk defa yer verilmesi (MEB, 1962) programın özgürlükçü yapısını desteklemektedir. Ancak yine de programda toplumu bireyin önüne koyan anlayış baskınlığını sürdürmüş; "birey toplum için" yaklaşımı terkedilmemiştir (Hesapçıŏlu, 2009). Ayrıca 1924'ten beri süregelen kız öğrencilere özel, erkek öğrencilere özel içerik stratejisinin 1962'deki programda da benimsenmesi cinsiyet eşitliğine ilişkin ülkedeki problemli algının varlığına işaret etmektedir (Carlson ve Kanci, 2016).

1962 Taslak Programı temelinde hazırlanan 1968 ilkokul Programı'ndaki sosyal bilgiler dersinde de bireye verilen önemin arttığı gözlemlenmiştir (MEB, 1968). Ayrıca 1962'deki programda olduğu gibi 1968' de de hem kültürel hem de etnisite ve kimlik farklılıklarına ilişkin çoğulcu ögelere yer verilmiştir (MEB, 1968). Ancak tüm bu olumlu durumlara rağmen birey-toplum dengesinde hala toplum baskın görünmektedir (Hesapçıŏlu, 2009). Ayrıca programda şive farklılıklarının bozukluk ya da düzeltilmesi gereken sorunlar olarak görülmesi bu konuda bazı yanlık veya önyargılı kavramsallaştırmaların programın felsefesine hâkim olduğuna ilişkin çıkarımı desteklemektedir (Alp ve Taştan, 2011). Dahası programda cinsiyet ayrımcılığına yönelik ön kabullerin devam ettiği bulgusuna da ulaşılmıştır (MEB, 1968).

1990 Sosyal Bilgiler Dersi Öğretim Programı'nda bireysel ve toplumsal farklılıklara ilişkin çoğulcu ifadeler yer alsa da; programın uygulandığı dönemde eğitime erişim veya alınan eğitimin niteliği bağlamında zengin-fakir eşitsizliği tek gerçek farklılık olarak belirgin bir şekilde ortaya çıkmıştır (Özoğlu, 2012). Hem kültürel hem de kimlik ve etnisite farklılıklarına ilişkin 1968'deki programla oldukça benzer bir içeriğe sahip olmasına rağmen; 1990 Sosyal Bilgiler Dersi Öğretim Programı'nda 1982 Anayasası'nın otoriter anlayışının izlerine rastlamak mümkündür (Şen, 2019). 1990 Sosyal Bilgiler Dersi Öğretim Programı́nı kendisinden önceki programlardan olumlu olarak ayrıştıran özelliği ise kadınların eşit temsili ile uyumlu konulara yer verilmiş olmasıdır (MEB, 1990). Bu durum cinsiyet eşitliği açısından yeterli olmasa bile kadının programlarda ilk defa daha eşitlikçi bir anlayışla yer alması bakımından dikkate değerdir (Esen, 2007).

1990'dan sonra uygulamaya konulan 1998 Sosyal Bilgiler Dersi Öğretim Programı'nda birey ile bireysel ve toplumsal farklılıklara ilişkin çoğulcu olarak nitelendirilebilecek birçok hedef, içerik, açıklama vb. ögeler bulunmasına rağmen (MEB, 1998); programın arkasındaki merkeziyetçi yapı ve standardize edici yaklaşım (Coşkun, 2016) bu ögelerin etkisini sınırlandırmıştır. Bununla birlikte ilk 
defa 1990 Sosyal Bilgiler Dersi Öğretim Programı'nın metninde eşitlikçi sayılabilecek ifadelerle yer verilen kadın haklarına ilişkin tutumun 1998'de de sürdürüldüğü gözlemlenmiştir (MEB, 1998).

2005, 2015 ve 2018 Sosyal Bilgiler Dersi Öğretim Programları birey ile bireysel ve toplumsal farklılıklar açısından Toland'ın (1998) analizi ışığında bir bütün olarak değerlendirildiğinde; 2002'den sonra ülkede yaşanan siyasi dönüşümle birlikte bireyin yeniden tanımlanması, ona yeni bir kimlik verilmesi, sisteme uyumlulaştırılması ve sistemin devamına kendisini adamasının sağlanması aşamalarının birer yansıması olarak düşünülebilir. Bu nedenle 2005 Programı başta olmak üzere 2002'den sonra geliştirilen programların önceki programlara oranla bireyi daha fazla öncelendiğine ilişkin araştırmalar (Akpınar ve Kaymakçı, 2012; Aktan, 2006; Öcal ve Yakar, 2015) çoğulcu anlayıştan ziyade yeni siyasi anlayışa uygun birey yetiştirme stratejisi ışığında yorumlanmalıdır (Çayır, 2015). Tablo 3'te Cumhuriyet'in ilanından itibaren sosyal bilgiler öğretimine yönelik hazırlanan programlarında "birey ile bireysel ve toplumsal farklılıklar" boyutuna ilişkin bulgular özet halinde sunulmuştur.

Tablo 3.

Programlarda birey ile bireysel ve toplumsal farklılıklar

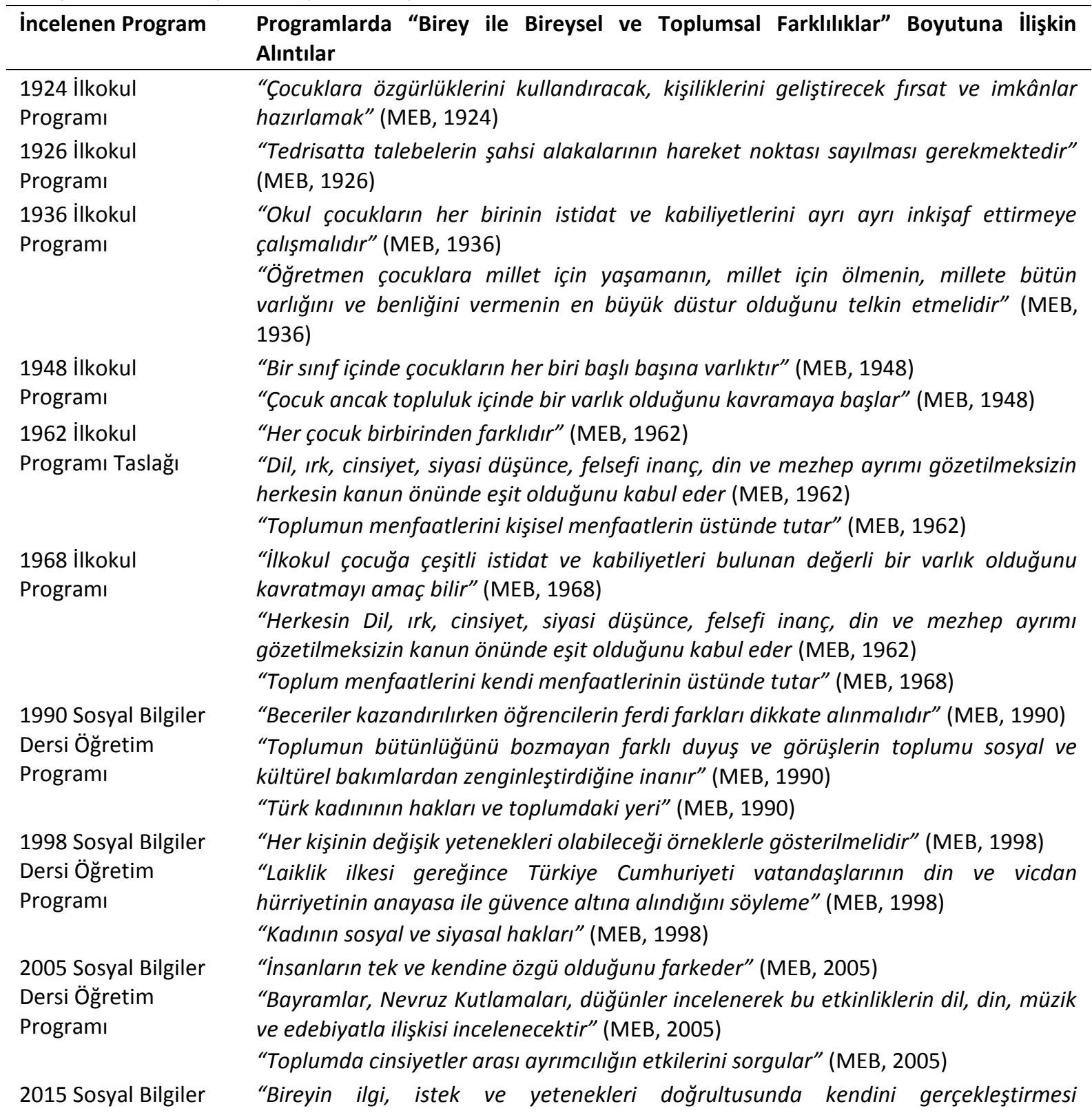




\section{Çoğulculuk Bağlamında Sosyal Bilgiler Öğretiminde “Düşünme Becerileri” (1924-2018)}

Sosyal bilgiler öğretimine yönelik 1924 İlkokul Programı'ndaki derslerde yer verilen düşünme becerilerinin yeni devletin vatandaşlarında din eksenli zihinsel yapının bilimsel temelli zihinsel yapıyla değiştirilmesini amaçladığı söylenebilir (Çetin, 2000). Bu nedenle programda eleştirel ve yaratıcı düşünme becerilerine yönelik tespit edilen ögeler laiklik temelli bir yaşantının düşünsel alt yapısını oluşturma stratejisiyle hazırlanmıştır (Başgöz, 2010). Ancak söz konusu düşünme becerilerine yapılan vurgunun yetersizliği ve derslerde kullanılması önerilen öğretim yöntemlerinin bu becerileri kazandırmaya uygun olmayışı programın eksiklerindendir (Türkoğlu ve Sarı, 2006).

1926 Illkokul Programı ile ilk defa benimsenen toplu öğretim anlayışının programdaki açıklamasından derslerin planlanmasında ve yürütülmesinde çoklu bakış açılarının kullanımının teşvik edildiği anlaşılmaktadır (Binbaşıoğlu, 2005; MEB, 1926). Bununla birlikte programın uygulayıcıları olan öğretmenlerin toplu öğretim başta olmak üzere programda benimsenen ilerlemeci yaklaşım ve getirdiği yeniliklere aşina olmayışları (Fer, 2010) kâğıt üzerinde kazandırılması önemsenen becerilerin ve oldukça nitelikli görünen programın uygulanmasında ciddi sorunların ortaya çıkmasına sebep olmuştur (Sakaoğlu, 2018).

1936 ilkokul Programı bireylerin sadık yurttaş olabilmeleri için bir taraftan güdülerini, yatkınlıklarını ve bağlılıklarını biçimlendirerek doğalarına sadakat ve fedakârlık aşılamak (Dilek, 2007); diğer taraftan onlardan eleştirel düşünme başta olmak üzere bilimsel sürecin gerektirdiği üst-düzey düşünme becerilerine sahip olmalarını beklemek (MEB, 1936) ikilemini yansıtmaktadır. O dönemin şartlarında birinci seçenek daha baskın bir strateji olarak benimsenmiştir (Keyman ve Kanci, 2011). Bu nedenle 1936 illkokul Programı'nda sosyal bilgiler öğretimini oluşturan derslerde üst-düzey zihinsel becerilerin kazandırılmasına yönelik hedef, içerik ve açıklamalara rastlansa da (MEB, 1936); temel olarak programın uygulanmasında izlenen yanlış politikalar nedeniyle bu ögelerin hayata geçirilmesi pek mümkün olmamıştır (Tazebay, 2000).

Programa sadece bilgi ve ders ekleyerek öğrencilerin hedeflenen davranışları kazanabileceği gibi oldukça hatalı bir strateji ile yapılandırılan 1948 illkokul Programı'nın (Bilgili, 2015) en çok eleştiri alan özelliği yoğun içeriğidir (Fer, 2010). Bu durum üst-düzey düşünme becerilerinin gelişimi için gerekli esnekliği ve çoklu bakış açısını kısıtlamıştır (Gülbahar, 2006). Dolayısıyla 1948 Programı'ndaki sosyal bilgiler öğretimini oluşturan derslerde yansıtıcı, yaratıcı, eleştirel düşünme becerilerinin vurgulandığı gözlemlenmiş olsa da (MEB, 1948); Dewey'in (1916) ifadesiyle bilginin istiflenmesini entelektüel bir aktivite olarak gören anlayışın hem programın geneline hem de sosyal bilgiler öğretimine ilişkin derslere egemen olduğu çıkarımında bulunulabilir (Dinç, 1999).

1962 İlkokul Programı Taslağı kendinden önceki programlara göre daha esnek bir anlayışla öğretmen ve öğrenciye uygulamada inisiyatif ve katılım hakkı verecek bir tarzda geliştirilmiştir (MEB, 1962). Bununla birlikte söz konusu katılım hakkı ve inisiyatif programın amaçlarını ya da içeriğini belirleyebilme özgürlüğünden ziyade önceden belirli amaç ve konuları düzenleme özerkliğini ifade etmektedir (MEB, 1962). Dolayısıyla bu özgürlük sınırlı bir özgürlük olduğu için (Tertemiz, 2000) öğrencilerin sahip olmaları amaçlanan üst-düzey düşünme becerilerinin kazandırılmasında arzu edilen başarı yakalanamamıştır (Akhan, Çiçek ve Mert, 2019). 
1968 İlkokul Programı́nda problem çözme ve proje yöntemlerine yer verilmesi, bireysel çalışma ilkesinin vurgulanması, öğrenci katılımının üzerinde ısrarla durulması (MEB, 1968) programdaki sosyal bilgiler dersinin de eleştirel, yaratıcı ve yansıtıcı düşünme becerilerini önceleyen bir yaklaşımla yürütülmesini gerektirmiştir (Yalçın ve Akhan, 2019). Ancak o dönem Türkiye'sinin dramatik bir gerçeği olan aşırı düşünsel kutuplaşmalar sığ, yüzeysel ve katı bir zihinsel yapıya zemin hazırlayarak; çok boyutlu, derinlemesine düşünebilen ve esnek bir mental yapının oluşmasına engel olmuştur (Sakaoğlu, 2018).

1968'deki program gibi 1990 Sosyal Bilgiler Dersi Öğretim Programı́nda da çoğulculuk bağlamında üst-düzey düşünme becerileri ile ilişkilendirilebilecek birçok amaç, ilke, yöntem ve açıklamaya rastlanılmıştır (MEB, 1990). Bununla birlikte 1970'li ve 1980'li yıllar Türkiye'sindeki kutuplaşmaların etkisinin devam etmesi (Güven, 2000); yoksulluk ile ilgili gerçekler (Güler, 2004); gelir dağılımı eşitsizlikleri (Çelebi, Güner, Kaya ve Korumaz, 2014) vb. faktörler okullarda yaratıcı, eleştirel ve yansıtıcı düşünme becerilerinden yoksun bir programın uygulanması sonucunu doğurmuştur (Binbaşıŏlu, 2005).

1998 Sosyal Bilgiler Dersi Öğretim Programı genel olarak hem öğrencilere hem de öğretmenlere soru ve ilgileri ile katkıda bulunma imkânı tanımayan (Yapıcı, 2004); toplumsal problemler etrafında eleştirel analize yönlendirmeyen (Çengel, 2006); kalıplaşmış yargıları sorgulama olanağı sağlamayan ve toplumdaki kökleşmiş çelişkileri ortaya çıkarmalarına izin vermeyen (Erdoğan, 2006) bir zihniyetle tasarlanmıştır. Dolayısıyla söz konusu bu olumsuz durumlar program metninde yer alan üst-düzey düşünme becerilerinin kazandırılmasının önündeki en büyük kısıtlamayı oluşturmuştur (Sakallıŏlu ve Çınar, 2003).

Hem 2005 hem 2015 hem de 2018 Sosyal Bilgiler Dersi Öğretim Programları'nda metin olarak yaratıcı, yansıtıcı, eleştirel ve esnek düşünme becerileri ile ilişkilendirilebilecek kazanım, öneri ve açıklamalar bulunmasına rağmen (MEB, 2005; MEB, 2015; MEB, 2018) yeni kimlik oluşturma hedefi ile uyumlu olarak okula yüklenen ve Foucoult (1980) tarafından mutlak ve kutsal gerçeği dağıtma misyonu olarak ifade edilen strateji bu becerilerin kullanılmasına imkân tanıyacak ölçüde özgürlükçü ve demokratik bir ortamın oluşmasını engellemisstir (Alp ve Taştan, 2011; Özbudun, 2014). Oldukça modern bir anlayışla hazırlandıkları iddia edilse de (MEB, 2005; MEB, 2015; MEB, 2018); esnek olmayan yapıları (Dursun, 2006), arkalarındaki merkeziyetçi felsefe (Şen, 2109) ve hazırlanmalarındaki ideolojik motivasyon (Eğitim-Iş, 2018) sebepleriyle oldukça yoğun bir şekilde eleştirilmiştir.

Cumhuriyet'in ilanından itibaren sosyal bilgiler öğretimine yönelik hazırlanan programlarında düşünme becerileri boyutuna ilişkin bulgular Tablo 4'te kısaca özetlenmiştir.

Tablo 4.

Programlarda düşünme becerileri

\begin{tabular}{|c|c|}
\hline İncelenen Program & Programlarda "Düşünme Becerileri" Boyutuna İlişkin Alıntılar \\
\hline $\begin{array}{l}1924 \text { ilkokul } \\
\text { Programı }\end{array}$ & "Öğrencilere körü körüne itaat ve bağlılığın zararlarını anlatmak" (MEB, 1924) \\
\hline $\begin{array}{l}1926 \text { ilkokul } \\
\text { Programı }\end{array}$ & "Muallim derste keşif ve tefekküre (zihinsel aktivite) çok yer vermelidir" (MEB, 1926) \\
\hline $\begin{array}{l}1936 \text { ilkokul } \\
\text { Programı }\end{array}$ & $\begin{array}{l}\text { "Okul çocuğu faaliyete, yaratmaya ve işe sevk edecek canlı bir muhit olmalıdır" } \\
\text { (MEB, 1936) }\end{array}$ \\
\hline & “Eğitimin temel taşı bilimsizliği gidermektir" (MEB, 1936) \\
\hline $\begin{array}{l}1948 \text { illkokul } \\
\text { Programı }\end{array}$ & "Asıl olan çocuğun yaratıcı ve aydın bir ahlak zihniyeti elde etmesidir" (MEB, 1948) \\
\hline 1962 illkokul & "Olayları ve davranışları daima yapıcı bir tenkitle değerlendirir" (MEB, 1962) \\
\hline
\end{tabular}




\begin{tabular}{|c|c|}
\hline Programı Taslağı & $\begin{array}{l}\text { "Öğretmene belirli sınırlar içinde seçim yetkisi verilerek programın yüklülüğü } \\
\text { giderilebilir" (MEB, 1962) }\end{array}$ \\
\hline 1968 ilkokul & “ilkokul çocuğu tenkidi (eleştirel) düşünmeye yöneltmelidir" (MEB, 1968) \\
\hline Programı & $\begin{array}{l}\text { "Türk okullarında öğrenciler olaylar bakışlarını yeterince } \\
\text { ayrıştıramıyorlar/farklılaştıramıyorlar" (Sylizowiez, 1973'ten akt. Güven, 2000; s. } \\
\text { 298) }\end{array}$ \\
\hline $\begin{array}{l}1990 \text { Sosyal Bilgiler } \\
\text { Dersi Öğretim }\end{array}$ & $\begin{array}{l}\text { "Küme çalışmaları ile düşünme, tartışma, kıyaslama, inceleme-araştırma, eleştirme } \\
\text { yetenekleri geliştirilebilir" (MEB, 1990) }\end{array}$ \\
\hline Programı & $\begin{array}{l}\text { "Türk okullarında öğrenciler doğruyu bulmak yerine ak ya da kara demeyi tercih } \\
\text { ediyorlar" (Sylizowiez, 1973'ten akt. Güven, 2000; s. 298) }\end{array}$ \\
\hline $\begin{array}{l}1998 \text { Sosyal Bilgiler } \\
\text { Dersi Öğretim } \\
\text { Programı }\end{array}$ & “Laiklik ilkesi gereği taassuba (bağnazlık) izin verilmediğini söyleme” (MEB, 1998) \\
\hline 2005 Sosyal Bilgiler & “Düşünme ve ifade özgürlüğünün önemini farkeder” (MEB, 2005) \\
\hline $\begin{array}{l}\text { Dersi Öğretim } \\
\text { Programı }\end{array}$ & $\begin{array}{l}\text { "Programlarda Mevlana, Mehmet Akif, Ömer Seyfettin gibi belirli yazar ve } \\
\text { düşünürlere yer verilmesine karşın bir Tevfik Fikret'e bir Yaşar Kemal'e hiç yer } \\
\text { verilmemesi tek yönlü bakış açısıyla eleştirel düşünmeyi öğrencilerin nasıl } \\
\text { kazanabileceğini sorgulamamıza yol açmaktadır" (Aykaç, 2007) }\end{array}$ \\
\hline $\begin{array}{l}2015 \text { Sosyal Bilgiler } \\
\text { Dersi Öğretim }\end{array}$ & $\begin{array}{l}\text { "Öğrencilerin eleştirel ve yaratıcı düşünme becerilerine sahip bireyler olmaları } \\
\text { amaçlanmaktadır" (MEB, 2015) }\end{array}$ \\
\hline Programı & "Çoklu bakış açılarına sahip olma becerisi üzerinde durulacaktır" (MEB, 2015) \\
\hline 2018 Sosyal Bilgiler & "Yenilikçi düşünebilme" (MEB, 2018) \\
\hline Dersi Öğretim & "Sosyal problemler üzerinde yansıtıcı düşünme" (MEB, 2018) \\
\hline Programı & $\begin{array}{l}\text { "Bir olayın çok boyutluluğunu fark edebilme" (MEB, 2018) } \\
\text { "Öğrenme-öğretme sürecinde çağdaş yöntem ve yaklaşımlar yerine dini, milliyetçi, } \\
\text { cinsiyet temelli, baskı ve empozeye dayalı yöntem, teknik ve yaklaşımlar } \\
\text { benimsenmiştir" (Eğitim-Sen, 2018; Taş, 2018) }\end{array}$ \\
\hline
\end{tabular}

\section{Çoğulculuk Bağlamında Sosyal Bilgiler Öğretiminde "Sosyal Sorunlara Duyarlılık" (1924-2018)}

1924 ilkokul Programı'nda sosyal bilgiler öğretimi tek ulus, tek dil ve tek kültür esaslarına dayanan yeni devletin vatandaşlarını bu esaslara ayak uyduracak bir donanımda yetiştirmeyi amaçlamıştır (Baran, 2010). Böyle bir hedefin belirlenmesinin temelinde bireylere yeni sosyal ve siyasal düzenin gerektirdiği değişikliklere uyum sağlama becerileri kazandırmak yatmaktadır (Binbaşıoğlu, 2005). Bu nedenle bireylerde aileye, ulusa ve devlete sadakat güçlendirilmeye çalışımış (Keyman ve Kanci, 2011); kamu yararı için çalışma bilinci yerleştirilmek istenmiş (Şen, 2019); yeni devletin işleyiş esaslarına yer verilmiş (MEB, 1924) dolayısıyla Cumhuriyetçi vatandaş nitelikleri vurgulanmıştır (Güven, 2000).

Toplumsal sorunları vurgulayarak halkın yekpare bir millet olmasını sağlama amacıyla hazırlanan 1926 illkokul Programı Cumhuriyet ilkelerini ön plana çıkararak halkı batılı devrimlere hazırlamayı öngörmüştür (Çetin, 2003). Programla uyumlu bir şekilde o dönem ders kitaplarında ulus kavramı; dil, kültür ve ideal birliği şeklinde din olgusuna yer verilmeden seküler bir anlayışla tanımlanırken (Bayri, 2008); askerlik yapma, vergi verme, oy kullanma, yasalara uyma gibi ödevlerle görev odaklı bir vatandaşlık anlayışı benimsenmiştir (Üstel, 2004). Ancak batıda insanların bizzat katıldığı yüzyıllar süren mücadelelerle ile sahip olabildikleri batılı kazanımların bu anlamda bir mücadeleye hiç katılmamış Türk halkına benimsetilmesinin zorluğu programın uygulanması aşamasında ortaya çıkmıştır (Çetin, 2000).

1936 İlkokul Programı́nda sosyal bilgiler öğretimi rejim için sadık, vatan için fedakâr, milletin varlığı için kendi varlığından vazgeçebilen bireylerin yetiştirilmesi hedefiyle tasarlanmıştır (MEB, 1936). Dolayısıyla toplumun çıkarlarını önceleyen vatandaşların hayal edildiği söylenebilir (İnce, 
2012). Bu duruma paralel olarak programın uygulandığı dönemin ders kitaplarında milliyetçi ve askeri kavramlara atıflar artarken (Şen, 2019); demokrasi kavramından neredeyse hiç bahsedilmemiştir (Üstel, 2011).

1948 illkokul Programı'nda sosyal bilgiler öğretimi daha önceki programlarda yer alan rejimi tanıtma ve benimsetme ile devlet teşkilatına ilişkin bilgi verme işlevlerini sürdürmüştür (Eroğul, 1992). 1948 Programı'nın farklı yanı ise demokrasi vurgusudur (Çapa, 2005). II. Dünya Savaşı sonrası artan insan hakları söylemleri ve ülkedeki çok partili siyasi hayata geçişin yansımaları böyle bir farklıı̆̆ın oluşmasında rol oynamıştır (Polat, 2011). Dolayısıyla "demokrasi” kelimesinin cazibesi etrafında yapılan tartışmaların ve o dönem ülkedeki siyasi atmosferde yeni yeni ortaya çıkmaya başlayan siyasi partilerin iktidar partisine yönelik eleştirilerinin etkisi ile programda demokrasi olgusu ön plana çıkmıştır (Binbaşıoğlu, 2005).

1962 ilkokul Programı Taslağı'nın en dikkat çekici özelliği özgürlüklere ilişkin olumlu tutumu olduğu için (Keskin ve Keskin, 2013) programdaki sosyal bilgiler öğretiminde demokratik ilkelere belirgin bir şekilde yer verilerek okulun demokrasinin yaşandığı bir topluluk haline getirilmesi amaçlanmıştır (MEB, 1962). Bununla birlikte, bu durum daha önceki programlarda yer alan rejime sadakat stratejisinin terkedilmesinde ziyade; bu stratejiye çok partili hayata geçiş ve 1961 Anayasası ile ülkenin içine girdiği demokratik sürece daha liberal bir perspektifin eklenmesi olarak değerlendirilebilir (Güven, 2000).

1948 ve 1962'deki programlara benzer bir şekilde 1968 ilkokul Programı'ndaki sosyal bilgiler dersinin de demokrasi bilincini bireylere demokratik bir ortamda yaşayarak kazandırma çabası içinde olduğu görülmektedir (Çatak, 2015). Ancak o dönem Türkiye'sinin içinde bulunduğu şartlar göz önüne alındığında bireylerin okulda edindikleri demokratik davranışları ne ölçüde hayatlarına yansıtabildikleri bir soru işaretidir (Çayır, 2015).

1990 Sosyal Bilgiler Dersi Öğretim Programı'nda eşitlik, demokrasi, insan hakları, bilinçli/sosyal sorunlara duyarlı vatandaşık şeklinde sıralanabilecek olgular güçlü bir şekilde vurgulanmış olsa da (MEB; 1990); bu olguların gerektirdiği her bireye eşit ve erişilebilir fırsatlar sunulması hiçbir zaman başarılamayan bir temenni olarak kalmıştır (Çelebi vd., 2014). Ayrıca programın uygulandığı dönemin ders kitaplarında hak ve özgürlükleri geri planda tutan; görev ve sorumlulukları önceleyen otoriter nitelikteki 1982 Anayasası'ndan alıntılara sıkça yer verilmiştir (Şen, 2019).

Toplumda pasif vatandaşlığın yüceltilmesi ve aktif vatandaşlığa ilişkin programdaki kazanımların bilgi düzeyinde kalması (Erdoğan, 2003) 1998 Sosyal Bilgiler Dersi Öğretim Programı'nın metninde yer alan demokratik ögeleri kısıtlamıştır. Zira o dönemdeki ders kitaplarında insan haklarına ilişkin tespit edilen sorunlar ile uluslararası tehdit gerekçesiyle aşırı milliyetçi, militarist ve otoriter bir devlet-vatandaş ilişkisinin öne çıkarıldığının belirlenmesi (Şen, 2019) bu bulguyla uyumludur.

Önceki programlara göre vatandaşlığı daha evrensel bağlamda ele aldığı iddiasıyla hazırlanan 2005 Sosyal Bilgiler Dersi Öğretim Programı ile bu program temelinde geliştirilen 2015 ve 2018 Sosyal Bilgiler Dersi Öğretim Programları́nda da sosyal sorunlara ve demokrasi bilincine yönelik derinlemesine sorgulamayı teşvik eden bir tutumun eksikliği göze çarpmaktadır (Çayır ve Gürkaynak, 2007; Korkmaz, 2017). 2005 Programı başta olmak üzere programların geliştirilmesinde Avrupa Birliği'ne uyum süreci, $A B D$ ve $A B$ ülkeleri ile birlikte dünyadaki farklı ülkelerin model alınması (MEB, 2005) gibi olumlu uygulamalara rağmen; itaat, uyum ve pasiflik mesajlarıyla yüklü geleneksel vatandaşlık eğitimi benimsenmeye devam edilmiştir (Şen, 2019). Yine de 2005 ve 2015 Sosyal Bilgiler Dersi Öğretim Programları'nda nispeten daha az hissedilen aktif vatandaşlık anlayışııın eksikliği, 
onlara göre daha geleneksel, milliyetçi ve korumacı bir anlayışın izlerini taşıyan 2018 Sosyal Bilgiler Dersi Öğretim Programı'nda daha belirgin bir şekilde görünmektedir (Korkmaz, 2017).

Tablo 5'te Cumhuriyet'in ilanından itibaren sosyal bilgiler öğretimine yönelik hazırlanan programlarında sosyal sorunlara duyarlıık boyutuna ilişkin bulgular özet halinde sunulmuştur.

Tablo 5.

Programlarda sosyal sorunlara duyarlılık

\begin{tabular}{ll}
\hline Incelenen Program & Programlarda "Sosyal Sorunlar Duyarlılık" Boyutuna Ilişkin Alıntılar \\
\hline 1924 İlkokul & "En mükemmel ve uygun idare şeklinin Cumhuriyet olduğunu fiilen öğrenmek" (MEB, \\
Programı & 1924) \\
1926 İlkokul & "Türkün iktisadi ve medeni kudret ve kabiliyeti hakkında çocuklarda itimat ve iman \\
Programı & oluşturmak" (MEB, 1926) \\
& "Türk say ve gayreti ile meydana gelen müesseseler" (MEB, 1926) \\
1936 İlkokul & "Çocukları Cumhuriyet rejimi için sadık ve fedakar birer yurttaş olarak yetiştirmek" \\
Programı & (MEB, 1936) \\
& "Her öğretmen Cumhuriyet rejiminin bizim için bir zaruret olduğunu çocuklarda \\
& sarsılmaz bir iman haline getirmeyi iş edinmelidir" (MEB, 1936)
\end{tabular}

1948 ilkokul

Programı

1962 ilkokul

Programı Taslağı

1968 ilkokul

Programı

1990 Sosyal Bilgiler

Dersi Öğretim

Programı

1998 Sosyal Bilgiler

Dersi Öğretim

Programı

2005 Sosyal Bilgiler

Dersi Öğretim

Programı

2015 Sosyal Bilgiler

Dersi Öğretim

Programı

2018 Sosyal Bilgiler

Dersi Öğretim

Programı
"Topluluğumuzun dayandığı demokrasi prensiplerini öğrenci okulda ve dershanede uygulamalı ve yaşayarak benimser" (MEB, 1948)

"Insan haklarına dayanan, milli, demokratik, laik, sosyal hukuk devleti ilkelerine bağlı vatandas yetiştirme" (MEB, 1962)

"Demokrasinin sadece bir idare şekli olmayıp herkesin karşılıklı hak ve sorumluluklar taşıdıkları bir yaşama şekli olduğu düşüncesini benimser" (MEB, 1968)

"Demokratik hayat ve Anayasamı" (MEB, 1990)

"Öğretmen daha okuldayken çocukları milli problemlerle ilgilenmeye alıştırmalıdır" (MEB, 1990)

"Cumhuriyetçilik ilkesi ile vatandaşların hak ve hürriyetlerinin garantiye alındığını söyleme" (MEB, 1998)

"Demokrasinin insan hakları için vazgeçilmez bir değer taşıdığını takdir eder" (MEB, 2005)

"Kamu güvenliği ve kamu sağlığı söz konusu olduğunda kanunlar çerçevesinde özgürlüklerin sınırlanabileceğini kavrar" (MEB, 2005)

"Türkiye Cumhuriyeti vatandaşları olarak hak, özgürlük ve sorumluluklarının bilincinde bireyler olmaları amaçlanmaktadır" (MEB, 2015)

"Toplumsal yaşamda doğacak sorunların en önemli güvencesi olarak örgütlü bir devlet gücünün varlığını kavrar" (MEB, 2018)

\section{Çoğulculuk Bağlamında Sosyal Bilgiler Öğretiminde “Çoğulcu Değerler” (1924-2018)}

Cumhuriyet'in Türk milliyetçiliğine dayalı bir anlayışla çok zorlu şartlar altında kurulması (Safran, 2010) ve yeni kurulan devletin devamlılığının sağlanması endişesi (Baran, 2010) 1924 ilkkokul Programı'ndaki sosyal bilgiler öğretiminin bu doğrultuda değerleri kapsayacak şekilde yapılandırılmasına neden olmuştur (Alp, 2017). Dolayısıyla 1924 illkokul Programı'nda vatan sevgisi, birlik-beraberlik, kahramanlık, cesaret vb. değerler etrafında öğrencilerin bireysel faydalarından ziyade ulusal çıkarlar için çalışmaları telkin edilmiştir (Polat, 2011). Bu nedenle kahraman bir milletin bireyleri olarak canları pahasına yurdu savunma misyonu yüceltilmiştir (MEB, 1924). 
1926 ilkokul Programı'ndaki sosyal bilgiler öğretiminin özellikle 1924-1934 yılları arasında yapılması planlanan ve dinin eğitim başta olmak üzere toplumsal hayat üzerindeki hâkimiyetine son verecek laiklik temelli devrimler ile (Öztürk, 2010) ulusal bir milliyetçilik anlayışı doğrultusunda gerçekleştirilmesi öngörülen sosyal inkılapları destekleyici değerleri (Cicioğlu, 2010) içerecek şekilde yapılandırıldığı söylenebilir. Dolayısıyla programda müşterek ve milli değerlere sürekli vurgu yapıldığı gözlemlenmiştir (MEB, 1926).

Atatürk ilke ve inkılapları temelinde tasarlanan 1936 İlkokul Programı'ndaki sosyal bilgiler öğretimi ortak ve milli değerler ile yardımlaşma ve dayanışmayı ön plana çıkarmıştır (Alp, 2017). Bu nedenle okula milli bir yurttaş tipinin üretim merkezi olma işlevi yüklenmiştir (Üstel, 2011). Bu doğrultuda programda İslami bir milliyetçilikten ziyade Türk kimliği odaklı bir milliyetçilik benimsendiği için (Bayri, 2008) değerlerin öğrencilere kazandırılmasında da Türklük ve İslamiyet arasındaki farklar belirginleştirilmeye çalışılmıştır (Çatak, 2015).

1948 ilkokul Programı́ndaki sosyal bilgiler öğretimini oluşturan dersler etik ve insani değerlere atıf yapmakla birlikte (MEB, 1948) programın milliyetçi ögeler etrafında bir değerler sistemi öngördüğü söylenebilir (Eroğul, 1992). Programda doğruluk, nezaket, sorumluluk, fedakârlık, işbirliği gibi değerlerin milli ögelerle yorumlanması makul bir strateji olarak öne çıksa da (Merey, 2015); Dewey'in (1916) ifadesiyle evrensel nitelikteki değerlerin milliyetçi bir bakış açısıyla yorumlanması taşıdıkları anlamların sınırlandırılması riskini barındırmaktadır.

Adalet, hürriyet, eşitlik değerleri etrafında bir toplum anlayışı öngören 1962 ilkokul Programı Taslağı'nda sosyal bilgiler öğretimi bireylerin insani değerleri, insan hakları ve birlikte çalışma becerileri kazanmalarını öngörmüştür (Green ve Karagöz, 1965; MEB, 1962). Bu nedenle taslak programda çoğulculuk açısından farklılıklara saygı, birlikte yaşama, iş birliği vb. değerler gözlemlenmiştir (MEB, 1962). 1962'deki program taslağında değerler açısından en dikkat çekici bulgu ise önceki programlara oranla nispeten daha az yoğun milliyetçilik eksenli bir anlayışın benimsenmesidir (Akpınar ve Kaymakçı, 2012). Bu doğrultuda programdaki hedeflerin yazımında kullanılan dil daha ılımlı, katı milliyetçiliği çağrıştıran hedef sayısı daha az, milliyetçilik vurgusu daha düşüktür (Bayri, 2008).

1968'deki sosyal bilgiler öğretimi de 1962 taslağı ile uyumlu bir şekilde demokratik değerleri ön planda tutmuştur. Ayrıca önceki programlarda romantik bir anlayış çerçevesinde bilimsel olarak doğruluğu kanıtlanmamış iddialarla destekli Türk milletine yönelik büyüklük ve üstünlük söylemleri üzerine kurulu milliyetçilik algısının (Keskin, 2012) 1962 ve 1968'deki programlarda daha rasyonel bir zemine oturtulmaya çalışıldığı söylenebilir (İnce, 2012).

1990 Sosyal Bilgiler Dersi Öğretim Programı́nda dayanışma, fikir ayrılıklarına saygı, barış, diğer milletlere saygı, din ve vicdan hürriyeti gibi çoğulculuk açısından olumlu değerlere yer verildiği gözlemlenmiştir (MEB, 1990). Bununla birlikte yazım dili ve ideolojik arka planı açısından 12 Eylül Darbesi'nin etkisiyle program girdiği açık bir şekilde anlaşılan Tehditler başlıklı bölümde aşırı korumacı ve tutucu bir tutumun benimsenmesi söz konusu değerlerin işlevsiz hale gelmesine sebep olmuştur (Kaplan, 2002).

1998' deki Sosyal Bilgiler Dersi Öğretim Programı'nda işbirliği ve yardımlaşma değerlerine yer verilirken (MEB, 1998) sosyal adalet ve kültürel farklılıklara saygı değerlerinin göz ardı edildiği gözlemlenmiştir. Dahası kendinden başka tüm devletleri ya da milletleri potansiyel düşman olarak gören tutumun sürdürülmesi (Keyman ve Kanci, 2011) programda yer alan değerlerin olabildiğince dar kalıba sokularak sınırlandırılması riskini ortaya çıkarmıştır. 
2005 Programı́ndan başlayarak 2015 ve 2018 Sosyal Bilgiler Dersi Öğretim Programları'nda bireylere kazandırımak istenen duyuşsal niteliklere değerler başlığı altında açık bir şekilde yer verilmiştir (MEB, 2005; MEB, 2015; MEB, 2018). Önceki programlara göre değerler açısından daha küresel bir yaklaşımla hazırlandıkları iddia edilen üç programda da adalet, dostluk, dürüstlük, sorumluluk gibi değerlere yer verilmiştir (MEB, 2005; MEB, 2015; MEB, 2018). Ancak değerler öğretimindeki bu yaklaşım değişiminin daha demokratik, çoğulcu ve özgürlükçü bir toplum yaratma hedefi doğrultusunda mı (Emel, 2018) yoksa önceki programlardan farklı değerlere yer verilerek yeni siyasi anlayışla uyumlu bireyler yetiştirme amacına yönelik mi olduğu tartışmalı bir konudur.

Cumhuriyet'in ilanından itibaren sosyal bilgiler öğretimine yönelik hazırlanan programlarında "çoğulcu değerler" boyutuna ilişkin bulgular Tablo 6' da kısaca özetlenmiştir.

Tablo 6.

Programlarda değerler

\begin{tabular}{|c|c|}
\hline İncelenen Program & Programlardan “Değerler” Boyutuna illişkin Alıntılar \\
\hline $\begin{array}{l}1924 \text { ilkokul } \\
\text { Programı }\end{array}$ & "Halkın, milletin ve istiklalin düşmanlarını öğrenmesi zaruridir" (MEB, 1924) \\
\hline $\begin{array}{l}1926 \text { ilkokul } \\
\text { Programı }\end{array}$ & $\begin{array}{l}\text { "Tedriste en esaslı hedef çocuklarda vatan muhabbeti uyandırmaktadır" (MEB, } \\
\text { 1926) }\end{array}$ \\
\hline $\begin{array}{l}1936 \text { ilkokul } \\
\text { Programı }\end{array}$ & $\begin{array}{l}\text { "Öğretmen talebeye en eski zamanlardan beri Türk ulusunun başka milletlerden } \\
\text { üstün yaşadığını anlatacaktır" (MEB, 1936) }\end{array}$ \\
\hline $\begin{array}{l}1948 \text { ilkokul } \\
\text { Programı }\end{array}$ & $\begin{array}{l}\text { "Talebeye Türklerin ziraatı, hayvan yetiştirmeyi, maden işlemeyi, bina kurmayı, yazı } \\
\text { yazmayı, heykel yapmayı nasıl ilk defa başardıklarını ve bunları dünyanın dört } \\
\text { bucağına naklederek başka milletlere verdikleri anlatılacaktır" (MEB, 1948) }\end{array}$ \\
\hline $\begin{array}{l}1962 \text { ilkokul } \\
\text { Programı Taslağı }\end{array}$ & $\begin{array}{l}\text { "Türk devrimlerine ve ülkülerine bağlı, çalışkan, araştıran, inceleyen, fedakar ve } \\
\text { fazilet sahibi bir yurttaş, mükemmel bir insan yetiştirmek" (MEB, 1962) }\end{array}$ \\
\hline $\begin{array}{l}1968 \text { ilkokul } \\
\text { Programı }\end{array}$ & $\begin{array}{l}\text { "Demokrasinin herkesin birbirlerinin görüş ve inançlarını saygı ve hoşgörüyle } \\
\text { karşıladıkları bir yaşama şekli olduğu düşüncesini benimser" (MEB, 1968) }\end{array}$ \\
\hline $\begin{array}{l}1990 \text { Sosyal Bilgiler } \\
\text { Dersi Öğretim } \\
\text { Programı }\end{array}$ & $\begin{array}{l}\text { "Öğrencilerin içten bir yakınlık duygusu ile vatandaşlarını tanımları ve onlarla yardım } \\
\text { ve işbirliği ruhu ile kaynaşmaları sağlanmalıdır" (MEB, 1990) }\end{array}$ \\
\hline $\begin{array}{l}1998 \text { Sosyal Bilgiler } \\
\text { Dersi Öğretim } \\
\text { Programı }\end{array}$ & "Iyi insan iyi vatandaş olarak yetişirler" (MEB, 1998) \\
\hline $\begin{array}{l}2005 \text { Sosyal Bilgiler } \\
\text { Dersi Öğretim } \\
\text { Programı }\end{array}$ & "Farklılıklara karşı saygı ve anlayış gösterir" (MEB, 2005) \\
\hline $\begin{array}{l}2015 \text { Sosyal Bilgiler } \\
\text { Dersi Öğretim } \\
\text { Programı }\end{array}$ & $\begin{array}{l}\text { "Yaşamın her alanında hoşgörü ve uzlaşma kültürünün oluşmasına ve gelişmesine } \\
\text { katkı sağlayan bireyler olmaları amaçlanmaktadır" (MEB, 2015) }\end{array}$ \\
\hline $\begin{array}{l}2018 \text { Sosyal Bilgiler } \\
\text { Dersi Öğretim } \\
\text { Programı }\end{array}$ & $\begin{array}{l}\text { "Toplumda uyum içerisinde yaşayabilmek için farklılıklara yönelik önyargıları } \\
\text { sorgular" (MEB, 2018) }\end{array}$ \\
\hline
\end{tabular}

\section{Tartışma, Sonuç ve Öneriler}

Cumhuriyet dönemiyle birlikte Türkiye'de genel olarak J. Dewey'in görüşleri doğrultusunda şekillenen pragmatizm felsefesine dayalı programların geliştirildiği resmi otoritelerce iddia edilmiştir (Çetin, 200). Neredeyse tüm eğitim programlarında, tüm hükümet ve parti politikalarında, kalkınma 
planlarında pragmatist felsefe ya da ilerlemecilik akımında dair görmek mümkündür (Sönmez, 1991). İlerlemecilik teorik olarak benimsenmesine rağmen; uygulamada esasicilik ve daimiciliğin baskın olduğu söylenebilir (Fer, 2010). Zira programlar genellikle ideolojik endoktrinasyon aracı olarak işlev gördüğü için ideolojik endoktrinasyona en uygun eğitim felsefeleri olan daimicilik ve esasiciliğin benimsenmesi son derece doğaldır (Çetin, 2003). Dolayısıyla kâğıt üzerinde çoğulcu ögeleri barındıran; bilimsel düşünen, üst-düzey zihinsel becerileri kullanabilen, bağımsız, özgür ve demokratik bireyler yetiştirme hedefleri (Binbaşıŏlu, 2005) uygulamada ezberci, çekingen, taklitçi ve diktacı tutuma sahip bireylerin yetiştirilmesine evrilmiştir (Gözütok, 2003). Çünkü geliştirilen programların derinlemesine analizi yapıldı̆̆ında;

$\checkmark$ Bilimsellikten ziyade siyasi kaygıların ağır bastı̆̆ı (Fer, 2010)

$\checkmark$ Eğitimcilerden ziyade bürokratların ön plana çıkması (Binbaşığlu, 2005)

$\checkmark$ Planlı bir projeden ziyade kişisel bir inisiyatifle yürütülmesi (Sakaoğlu, 2018)

vb. durumlar göze çarpmaktadır. Dolayısıyla toplumsal konsensüs sağlama amacı güdülmeden her siyasi iktidar kendi döneminde programları kendi amaçları doğrultusunda yenileme politikası izlemiştir (Sakaoğlu, 2018).

Birey-toplum denkleminde Cumhuriyet tarihi boyunca genelde tüm eğitim programları özelde ise Sosyal Bilgiler Dersi Öğretim Programları batıda Durkheim'ın Türkiye'de ise Ziya Gökalp'in fikirleri ile şekillendirdiği, bireyden çok toplumu ön planda tutan sosyolojik bakış açısıyla yapılandırılmıştır (Hesapçığlu, 2009). Kadın ve erkeğe ilişkin cinsiyet rollerinde de aynı şekilde toplumun ihtiyaçlarına uygun olarak kadın, destekleyici ve bakıc rolleri ile ön plana çıkarılmışır (Oğuz, 2007). Dolayısıyla çoğulculuğun önem verdiği birey; bireysellik; bireysel, etnik, kültürel, cinsiyet, dil farklılıkları vb. kavramlar genellikle toplum, topluma uyum, kolektif yapı vb. olguların gölgesinde kalmıştır (Şen, 2019). Bu nedenle programlarda insan yerine devlet/toplum; iyi insan yerine iyi vatandaş vurgulanmıştır (Çayır, 2015).

Düşünme becerileri açısından Türkiye'de geliştirilen programlara yönelik olarak üst-düzey zihinsel becerilerin kazandırılmasını uygun ortamlar sunulmadığı (Köprülü, 2018); pratiğe değil bilginin istiflenmesine önem verildiği (Fer, 2010); hayattan kopuk bir bakış açısıyla tasarlandıkları (Türkoğlu, 2010); esnek olamayan, inisiyatif olanağı tanımayan, ezberciliğe iten bir yapıya sahip oldukları (Gözütok, 2003) vb. eleştiriler yapılmaktadır. Bu doğrultuda araştırma kapsamında incelenen Sosyal Bilgiler Dersi Öğretim Programlarının metinlerinde genel olarak yaratıcı, yansıtıcı ve esnek düşünme becerileriyle ilişkilendirilebilecek ögeler bulunsa da; kimi zaman programların otoriter arka planı (Çayır, 2015), kimi zaman ideolojik kutuplaşmalar (Güven, 2000), kimi zaman programların esnek olmayan yapısı (Acat, 2006), kimi zaman fiziksel yetersizlikler (Aykaç, 2011), kimi zaman öğretmen eğitimindeki eksiklikler (Öztürk, 2010) kimi zaman da bu durumların tamamı bu becerilerin gelişimi için elverişli şartların oluşturulmasını engellemiştir.

Sadece Türkiye'de değil genel olarak tüm ulus devletlerde okullara temel olarak devlet ve kurumların ideolojisini kitlelere ulaştırma misyonu yüklenmiştir (Erdoğan, 2006). Geleneksel vatandaşlık eğitimi anlayışını yansıtan bu misyonun benimsenmesiyle Türkiye tarihinde Sosyal Bilgiler Dersi Öğretim Programları apolitik veya depolitize bir vatandaş profilini teşvik eden (Şen, 2019), katııımcı vatandaşlık becerilerini göz ardı eden (Doğanay, 2003), demokrasiyi çoğulcu bir anlayıştan ziyade çoğunlukçu bir bakış açısıyla yorumlayan (Erdoğan, 2006), birey yerine kolektif olana (devlet, ülke, millet) yoğunlaşan bir tarzda yapılandırılmıştır (Şen, 2019). Böyle bir tutumun benimsenmesinde merkeziyetçi devlet anlayışı ile birlikte (Hesapçıoğlu, 2009) 1950'lerden itibaren demokratikleşme sürecinde yaşanan kesintilerin (Fer, 2010) rol oynadığı söylenebilir.

Yoğunluğu dönemsel olarak farklılık gösterse de Türkiye'deki Sosyal Bilgiler Dersi Öğretim Programlarının genel anlamada tek uluslu homojen yapıyı destekleyici değerler içerdiği çıkarımında 
bulunulabilir (Alp ve Taştan, 2011). Söz konusu bu değerlerin benimsenmesinde Türkiye'deki modernleşme anlayışının bireysel özgürlükler yerine bireyi devletin aracı kılmayı amaçlaması etkili olmuştur (Keyman ve Kanci, 2011). Dolayısıyla Sosyal Bilgiler Dersi Öğretim Programlarında gönüllü bir birliktelikten ziyade zorunlu görev ve iş bölümü temelinde fedakârlık, milliyetçilik, vatanseverlik, birlik-beraberlik, iş birliği, dayanışma, sosyal uyum ve sorumluluk gibi değerlerin yüceltildiği gözlemlenmiştir (Çetin, 2003).

Çoğulculuk, eleştirel program teorisi ve sosyal bilgiler öğretimine ilişkin alanyazın çalışmaları doğrultusunda incelenen 1924-2018 döneminde yayımlanan yazılı sosyal bilgiler dersi öğretim programlarının analizine ve yukarıda yapılan tartışmaya dayalı olarak çalışma kapsamında program geliştirme ve öğretim alanına, öğretmen eğitimine, gelecekte yapılacak araştırmalara yönelik aşağıdaki öneriler sunulmuştur:

$\checkmark$ Öğretim programları çoğulcu ve kapsayıcı bir yaklaşımla bireylere ihtiyaçlarına yönelik çoklu seçenekler sunabilecek bir yapıda hazırlanmalıdır.

$\checkmark$ Öğretim programları soyut, nesnel hedeflerden ziyade bireylerin öznel hedefleri ile şekillendirebilecekleri bir yapıda hazırlanmalıdır.

$\checkmark$ Herkes için tek tip, merkezi ve standart programlar yerine geniş seçme özgürlüğü sağlayan bireysel haklar, vatandaşlık hakları, demokrasi, sivil kimlik, sivil toplum, eşitlik ve özgürlük temalarını içeren çekirdek ve alternatif öğretim programları geliştirilmelidir.

$\checkmark$ Eğitim ve öğretim programlarının her aşamasında bireylere kendileri ile ilgili karar alma süreçlerini etkileme gücü ve inisiyatif kullanma olanağı sağlanmalıdır.

$\checkmark$ Öğretim programları çoğulcu bir perspektifle dil, din, kültür, yaşayış tarzı, cinsiyet ve etnik farklııklar vb. yansıtacak şekilde yapılandırımalıdır.

$\checkmark$ Hizmet öncesi ve hizmet içi öğretmen eğitiminde programın felsefesi ve arkasındaki ideoloji ve güç ilişkilerini sorgulayan etkinliklere yer verilmelidir.

$\checkmark$ Öğretmenlere öğretim programlarında öğrenci ihtiyaçları ve çevre olanakları doğrultusunda değişiklik yapma özgürlüğü verilmeli; hatta bu özgürlüğü kullanma konusunda teşvik edilmelidirler.

$\checkmark$ Öğretim programları tek tip bir ideoloji veya bakış açısını empoze etmek yerine, entelektüel açıdan eleştiri geleneğinin oluşmasına katkı sağlayacak şekilde demokratik bir yaklaşım ve çoklu bakış açılarıyla tasarlanmalıdır.

$\checkmark$ Bilginin sınıf seviyelerine göre belirlendiği doğrusal bir tasarım yerine öğrencileri ulaşacakları son nokta ile sınırlandırmadan (fabrika metaforu) eğitim sürecinde her öğrencinin farklı bir yolculuğu (seyahat metaforu) olduğu kabul edilerek yaratıcılık ve hayal gücü ile harmanlanmış bir öğretim programı tasarımı benimsenmelidir.

$\checkmark$ Hoşgörü, saygı, çeşitlilik gibi çoğulcu kavram ve değerlerin sınıf yönetimi ve öğrenmeöğretme ortamlarındaki vurgusu artırılmalıdır.

$\checkmark$ Öğretim programları ekonomik eşitsizlik, ötekileştirme, ayrımcılık, toplumsal cinsiyet eşitsizliği, politik ve kültürel engellerle mücadele edecek şekilde toplumsal değişimi hedeflemelidir.

$\checkmark$ Eğitim politikaları geliştirilirken demokratik katılım, toplumsal uzlaşı, şeffaflık ve toplumdaki birey ya da grupların, azınlıkların talep ve hassasiyetleri göz önüne alınmalıdır.

$\checkmark$ Çoğulcu paradigma bağlamında kapsayıcı eğitim, kültüre duyarlı eğitim, çeşitlilik eğitimi vb. konularda daha fazla ve daha nitelikli araştırma çalışmaları yürütülmelidir.

Eğitim bilimciler ve araştırmacılar, kadın ve cinsiyet, göç, popüler kültür, post-pozitivizm, teolojik program kuramı, politik program kuramı, fenomonolojik program kuramı, çok kültürlü ve çoğulcu paradigma vb. konu ve alanlarda ilişkin yapılan çalışmalardan yararlanmaya ve bu konularda eğitim bilimleri literatürüne katkı sağlayacak nitelik ve nicelikte araştırma yürütmeye teşvik edilmelidir. 


\section{Kaynakça}

Acat, B. (2006). Hayat boyu öğrenme anlayışı içinde yeterliliğe dayalı okul modeli. Ş. Abak (Der.), Türk eğitim sisteminde yeni paradigma arayışları (s. 125-148) içinde. Ankara: Eğitim-Bir-Sen Yayınları.

Akar, H. (2016). Durum çalışması. A. Şaban ve A. Ersoy (Ed.), Eğitimde nitel araştırma desenleri (s.111-151) içinde. Ankara: Anı Yayıncılık

Akbaş, O. (2013). Eğitim bilimlerinde yeni yönelimler. E. Karip (Ed.), Eğitim bilimine giriş (s.327-358) içinde. Ankara: Pegem Akademi.

Akhan, N. M., Çicek, S. ve Mert, H. (2019). Cumhuriyetten günümüze sosyal bilgiler programlarında değişen "iyi vatandaşlık” algısı. Anemon Muş Alpaslan Üniversitesi Sosyal Bilimler Dergisi, 7(2), 9-19.

Akhan, O. ve Yalçın, A. (2016). Sosyal bilgiler öğretim programlarında çok kültürlü eğitimin yeri. Trakya Üniversitesi Sosyal Bilimler Dergisi, 4(2), 12-27.

Akpınar, M. ve Kaymakçı, S. (2012). Ülkemizde sosyal bilgiler öğretiminin genel amaçlarına karşılaştırmalı bir bakış. Kastamonu Eğitim Dergisi, 20(2), 605-626.

Aktan, S. (2006). Sosyal bilgilerin bir öğretim alanı olarak gelişimi ve cumhuriyet dönemi program tasarılarına olan yansımalar. (Yayınlanmamış Yüksek Lisans Tezi), Balıkesir Üniversitesi Sosyal Bilimler Enstitüsü, Balıkesir.

Aktürk, Ş. (2018). One nation under Allah? Islamic multicultiralism, muslim nationalism and Turkey's reforms for Kurds, Alevis and Non-muslims. Turkish Studies, 19(4), 523-551.

Alp, H. (2017). Meşrutiyetten cumhuriyete Türkiye'de ilköğretim ve müfredat programları. İstanbul: Nobel Akademi Yayıncılık.

Alp, S. ve Taştan, N. (2011). Türkiye'de ırk veya etnik köken temelinde ayrımcılığın izlenmesi raporu (1 Ocak- 31 Temmuz, 2010). İstanbul: İstanbul Bilgi Üniversitesi.

Alvarez, L. (2018). Education and pluralism: Towards a democratic theory of education in Europe. Intercultual Human Rights Review, 349-360

Appelbaum, P. (2002). Multicultural and diversity education. California: Library of Congress Cataloque

Applebee, A. N. (1996). Curriculum as conversation: transforming traditions of teaching and learning. Chicago: University of Chicago Press

Apple, M. (1985). The culture and commerce of textbook. Journal of Curriculum 147-162 17(2).

Apple, M. (2012). Eğitim ve iktidar. (Çev. E. Bulut). İstanbul: Kalkedon Yayınları.

Aykaç, N.(2007). İlköğretim programında yer alan etkinliklerin öğretmen görüşleri doğrultusunda değerlendirilmesi. Ahi Evran Üniversitesi Kırşehir Eğitim Fakültesi Dergisi 19-35 (2).

Aykaç, N. (2011). Türkiye Cumhuriyeti'nin kuruluşunda günümüze sosyal bilgiler programının eğitim programı öğeleri açısından değerlendirlmesi, Illköğretim Online. 10(2). 406-420.

Banks, J. A. (2000). Multicultural education: issues and perspectives. New York: John Wiley and Sons

Banks, J. A. (2007). Diversity and citizenship education: Global perspectives. San Fransisco, CA: Jossey Bass Press

Banks, J. A. (2008). Diversity, group identity and citizenship education in a global age. Journal of Educational Researcher, 37, 129-139.

Baran, T. A. (2010, Ağustos). Atatürk'ün eğitim düşüncesi. M. A. Parlak (Haz.), Cumhuriyet dönemi eğitim politikaları sempozyumu bildiriler kitabı (s. 13-34) içinde. Ankara: Atatürk Araştırma Merkezi.

Başgöz, İ. (2010, Ağustos). Cumhuriyetin ilk yıllarında Türkiye'de eğitimin genel görünümü. M. A. Parlak (Haz.), Cumhuriyet dönemi eğitim politikaları sempozyumu bildiriler kitabı (s. 7-12) içinde. Ankara: Atatürk Araştırma Merkezi.

Bayri, H. (2008). Türkiye'de kimlik siyaseti sorunu ve ulusal kimlik (1980 sonrası döneme sosyo-politik bir bakış). (Yayımlanmış Doktora Tezi). Atatürk Üniversitesi Sosyal Bilimler Enstitüsü. Erzurum

Biesta, G. (2013). Knowledge, judgement and the curriculum on the past prenset and the future of the idea of the practial. Journal of curriculum Sudies, 45(5), 684-696.

Bilgili, A. S. (2015). Geçmişten günümüze sosyal bilimler ve sosyal bilgiler. A. S. Bilgili (Ed.), Sosyal bilgilerin temelleri, (s. 2-34) içinde. Ankara: Pegem Akademi Yayıncılık.

Binbaşıoğlu, C. (2005). Türkiye'de eğitim bilimleri tarihi. Ankara; Anı Eğitim Yayıncılık

Bümen, N. T. ve Aktan, S. (2014). Yeniden kavramsallaştırma akımı ışı̆̆ında Türkiye'de eğitim programları ve öğretim alanı üzerine özeleştirel bir çözümleme. Kastamonu Eğitim Dergisi, 22(3), 1123-1144.

Carlson, M. ve Kanci, T. (2016). The nationalized and gendered citizen in a global world-examples from textbooks, policy and steering documents in Turkey and Sweden. Gender and Education 29(3), 313-331. 
Cartes. C. E. (1991). Pluribus and unum: The quest for community amid diversity. The Magazine of Higher Learning, 23(5), 8-13.

Caymaz, B. (2008). Citizenship education in Turkey. M. Nahl, A. Akkoyunlu ve S. Wingley (Eds.), Education in Turkey (s.195-227) içinde. Münster: Woxmann.

Chambers. R. (2010). Paradigms, poverty and adaptive pluralism. LDS Working Papers, 344, 01-57.

Cicioğlu, H. (2010). Türkiye Cumhuriyet'inde orta öğretimin gelişimi. M. A. Parlak (Haz.), Cumhuriyet dönemi eğitim politikaları sempozyumu bildiriler kitabı (s.137-172) içinde. Ankara: Atatürk Araştırma Merkezi.

Cirik, ì. (2008). Çokkültürlü eğitim ve yansımaları. Hacettepe Üniversitesi Eğitim Fakültesi Dergisi, 34, 27-40.

Conyer, B. (2011). Pluralism in Jewish education. Amsterdam: Spinger.

Coşkun, H. (2016). Kültürlerarası eğitim: Türkiye ve Almanya örneği. Ankara: Kondrad-Adenauer-Shifturg

Crawford, E. O. ve Kirby, M. M. (2008). Fostering students global awarenes: technology applications in social studies teaching and learning. Journal of Curriculum and Instruction, 2(1), 56-73.

Creswell, J. W. (2013). Qualitative inquiry and research design: chnasing among five approaches. Thousand Oaks: Sage.

Crouch, M. ve McKenzie, H. (2006). The logic of small samples in interview-based qualitative research. Social Science Information, 45(4), 483-499.

Çapa, M. (2005). Cumhuriyet'in ilk yıllarında tarih öğretimi. Ankara Üniversitesi Türk Inkılap Tarihi Enstitüsü Atatürk Yolu Dergisi, 8 (29), 39-55.

Çatak, M. (2015). Türkiye'de sosyal bilgiler öğretim programlarının incelenmesi. EKEV Akademi Dergisi, 19(62), 69-74.

Çayır, K. (2009). We should be ourselves before being a European: The new curriculum, new textbooks and Turkish modernity. Education Sciences: Theory \& Practice 9(4). 1681-1690.

Çayır, K. (2015). Citizenship, nationality and minarities in Turkey's textbooks: from politics of non-recognition to difference multiculturalism. Comparative Education 51(4). 519-536.

Çayır, K., ve Gürkaynak, i. (2007). The state of citizenship education in Turkey past and peresent. Jaurnal of Sociol Science Education 6(2). 50-58.

Çelebi, M., Güner, H., Kaya, T. G. ve Korumaz, M. (2014). Neo-liberal eğitim politikaları ve eğitimde fırsat eşitliği bağlamında uluslararası sınavların (PISA, TIMSS ve PIRLS) analizi. Tarih, Kültür ve Sanat Araştırmaları Dergisi. 3(3), 33-75.

Çengel, Y. (2006) AB sürecinde eğitimin modern dünya standartlarına çıkarılması. Ş. Abak (Der.), Türk eğitim sisteminde yeni paradigma arayışları (s.345-348) içinde. Ankara: Eğitim- Bir-Sen Yayınları

Çetin, H. (2000). Eğitimden idealist beklentiler pragmatist yaklaşımlar. Ankara Üniversitesi Eğitim Bilimleri Fakültesi, 27(2), 660-678

Çetin, H. (2003). Modernleşme ve Türkiye'de modernleşme krizleri. Ankara: Siyasal Kitapevi.

Çoban, O. ve Akşit, i. (2018). 2005 ve 2017 sosyal bilgiler öğretim programlarının öğrenme alanı, kazanım, kavram, değer ve beceri eğitimi boyutları açısından karşılaştırılması. Tarih, Kültür ve Sanat Araştırmaları Dergisi, 7 (1), 479-505.

Davison, A. (2003). Turkey a secular state? The challenge of desciption. The South Atlantic Quarterly, 202(213), 333-350.

Dedeoğlu, S. (2009). Eşitlik mi ayrımcılık mı? Türkiye'de sosyal devlet, cinsiyet eşitliği politikaları ve kadın istihdamı. Çalışma ve Toplum, 2(21), 41-54.

Dewey, J. (1916). Democracy and education. New York: Macmillan

Dewey, J. (1922). Individuality, equality and superiority. Carbondale: Southern Illinois University Press.

Dewey, J. (1927). The public and its problems. Athens: Ohio Universty Press

Dewey, J. (1934) A common faith. New Haven: Yale University Press

Dilek, D. (2007). Tarih derslerinde öğrenme ve düşünce gelişimi. Ankara: Pegem Akademi Yayıncılık

Dinç, S. (1999). Cumhuriyet Dönemi'nde yapılan milli eğitim şuraları ve alınan kararların uygulanması (19231960). (Yayımlanmamış Yüksek Lisans Tezi). Hacettepe Üniversitesi Atatürk İlke ve İnkılap Tarihi Enstitüsü, Ankara

Doğanay, A. (2003, Mayıs). Sosyal bilgiler eğitiminin genel amaçları nasıl olmalıdır? Tebliğler: I. Sosyal Bilimler Eğitimi Kongresi (s. 204-215). İçinde. Ankara: Milli Eğitim Bakanlığı Yayınları.

Dursun, D. (2006). Küresel çağda eğitim üzerine bazı notlar. Ş. Abak (Der.), Türk eğitim sisteminde yeni paradigma arayışları (s.232-242) içinde. Ankara: Eğitim- Bir- Sen Yayınları. 
Eğitim-Bir-Sen (2018, Temmuz). Müfredatta daha atılması gereken çok adım var. 10 Kasım 2018 tarihinde http://www.ebs.org.tr adresinden erişilmiştir

Eğitim-Iş (2018, Temmuz). Taslak öğretim programları değerlendirme raporu. 10 Kasım 2018 tarihinde http://www.egitimis.org.tr adresinden erişilmiştir.

Eğitim- Sen (2018, Temmuz). Eğitim müfredatı değişiklikleri ve taslak öğretim programları raporu. 10 Kasım 2018 tarihinde http://www.egitimsen.org.tr adresinden erişilmiştir.

Emel, N. (2018). 1980'den günümüze Türk eğitim sisteminde yeniden yapılandırma girişimleri. Azerbaycan Mektebi, 2, 139-150.

Erdoğan, E. (2003). Türk gençliği ve siyasal katılım: 1999-2003. İstanbul: Toplumsal Katılım ve Gelişim Vakfı.

Erdoğan, M. (2006, Kasım). Eğitim ve öğretimi özgürleştirmek. Ş. Abak (Der.), Türk eğitim sisteminde yeni paradigma arayışları bildiriler kitabı (s. 284-289) içinde. Ankara: Eğitim Bir-Sen Yayınları.

Eroğul, C. (1992). Çok partili düzenin kuruluşu. I. Schick ve A. Tonak (Der.), Geçiş sürecinde Türkiye (s.171-231) içinde. İstanbul: Belge Yayınları

Ersoy, A.F. (2013). Global citizenship education in social studies: experiences of Turkısh teachers and students in international conflict and war. Eğitimde Nitel Araştırmalar Dergisi, 1(1), 7-30.

Ertuğrul, H. (2000). Osmanlı'dan günümüze ilköğretim sisteminin amaçlarına kronolojik bir bakış. Kastamonu Eğitim Dergisi, 8, 117-122.

Esen, Y. (2007). Sexism in school textbooks prepared under education reform in Turkey. Journal of Critical Education Political Studies, 5(2) , 466-493.

Fabretti, V. (2011). The public vs private school choice debate: pluralism and recognition in education. Italian Journal of Sociology of Education, 1. 115-135

Fallace, T. (2012). Race, culture and pluralism: the evaluation of Dewey's vision for a democratic curiculum. Journal of Curriculum Studies, 44(1), 13-35.

Fer, S. (2010). 1923 yılından günümüze cumhuriyet dönemi ilköğretim programları üzerine bir inceleme. M. A. Parlak (Haz.), Cumhuriyet dönemi eğitim politikaları sempozyumu bildiriler (s.97-136) içinde. Ankara: Atatürk Araştırma Merkezi.

Foucoult, M. (1980). Power, knowledge, selected interviews and other writing. London: Harvester Wheatsheaf

Frankel, J., Wallen, N. ve Hyun, H. (2012). How to desing and evaluate research in education. New York: McGrow-Hill

Gay, G. (1990). Achieving educational quality through curriculum desegration. Virginia Arlington: Phi Delta Kappan

Gay, G. (2010). Culturally responsive teaching. New York: Teachers College Press.

Giroux, H., ve Purpel, D. (1983). The hidden curriculum and politics of education. New York: Routledge.

Goodman, D. (2001). Living and teaching in an unjust world. Porsmouth: Heinemann.

Görmez, E. (2018). Güncellenen sosyal bilgiler programının politik okuryazarlık bakımından yeterliliği. Anemon Muş Alpaslan Üniversitesi Sosyal Bilimler Dergisi, 6, 109-114.

Gözütok, F. D. (2003). Türkiye' de program geliştirme çabaları. Milli Eğitim Dergisi, , 160(1), 90-102

Grant, L. D. (2011). Pluralistic approaches to Israel education. Journal of Jewish Education, 77(1), 4-21.

Green, B. (2003). Curriculum inquiry in Australia: Toward a local geneology of the curriculum field. International Handbook of Curriculum Reserach, 7, 123-141.

Green, E. ve Karagöz, S. (1965). Yeni ilkokul programı taslağı ve ünite çalışmaları. Ankara: Öğretmeni İşbaşında Yetiştirme Bürosu Yayınları.

Grumet, R. (1988). Bitter milk: Women and teaching. Amherst: University of Massachusetts Press.

Gustafsson, J. (2017). Single case studies vs multiple case studies: A comparitive study. Academy of Business, Engineering and Science. 12(1), 1-12

Gülbahar, G. (2006). Cumhuriyet dönemi (1920-1950) Türk eğitim sisteminin felsefi temelleri. (Yayımlanmamış Yüksek Lisans Tezi). Kırıkkale Üniversitesi Sosyal Bilimler Enstitüsü. Kırıkkale.

Güler, A. (2004). Türk eğitim politikalarının tarihsel süreci. Ankara: Yeryüzü Yayınları.

Güven, i. (2000). Türkiye'de eğitim, devlet ve ideoloji. Ankara: Siyasal Kitapevi.

Hesapçığlu, M. (2009). Türkiye'de cumhuriyet döneminde eğitim politikası ve eğitim felsefesi. M. Ü. Atatürk Eğitim Fakültesi Eğitim Bilimleri Dergisi, 29, 121-138.

Hesapçığlu, M. (2010, Temmuz). Türkiye'de cumhuriyet devri eğitim hareketlerinin dayandığı felsefi eğilimler. M. A. Parlak (Haz.), Cumhuriyet dönemi eğitim politikaları sempozyumu bildiriler kitabı (s.53-60) içinde. Ankara: Atatürk Araştırma Merkezi. 
Hicks, D. (2003). Thirty years of global education: A remainder of key principles and precedents. Educational Review, 55(3), 265-275.

Iannone, R. (1995). Chaos theory and its implications for curriculum and teaching. Education, 115(4), 541-548.

Ince, B. (2012). Citizenship education in Turkey inclusive or exclusive. Oxford Review of Education 38(2), 115131.

Kabadere, T. (2010). Lise biyoloji öğretim programlarının cumhuriyetten günümüze değişimlerini etkileyen unsurlar ve analizleri. (Yayımlanmamış Doktora Tezi) Gazi Üniversitesi Eğitim Bilimleri Enstitüsü, Ankara.

Kan, Ç. (2010). ABD ve Türkiye'de sosyal bilgilerin tarihsel gelişimi. Gazi Eğitim Fakültesi Dergisi, 30(2), 663-672.

Kaplan, P. (2017, Ocak). Yeni müfredata tepki: 100 bini aşkın şikayet ve öneri. 11 Kasım 2018 tarihinde http://www.pervinkaplan.com adresinden erişilmiştir.

Kaplan, S. (2002). Din u devlet all over again? The politics of military secularism and religious militarism in Turkey following the 1980 coup. International Journal of Middle East Studies 34(1), 113-127.

Karakuş, E., Mutlu, E., ve Çoşkun, Y. (2018). Toplumsal cinsiyet eşitliği açısından öğretim programlarının incelenmesi. Istanbul Üniversitesi Kadın Araştırmaları Dergisi, (17), 31-54.

Kaya, I.., ve Aydın, H. (2014). Çoğulculuk, çok kültürlü ve çok dilli eğitim. Ankara: Anı Yayıncılık

Keller, E. M. (1954). Köy okullarında modern müzik çalışmaları. K. Wofford (Ed.), Küçük köy okullarında yeni öğretim örnekleri (s. 25-28) içinde. İstanbul: Maarif Basımevi.

Keskin, Y. (2012), Türkiye'de 1970'li yıllardan günümüze kadar yayınlanmış ilkokul, ortaokul ve ilköğretim programlarında yer alan tarih dersi konularının dönemlere göre incelenmesi. International Online Journal of Educational Sciences, 4(2), 442-461.

Keskin, Y., ve Keskin, S. (2013), İlkokul (Illköğretim) sosyal bilgiler programlarında milli bilinç ve barış değerinin tarihsel serüveni. TSA, 17(3), 51-86.

Keyman, E.F., ve Kanci, T. (2011). A tale of ambiquity: citizenship, nationalism and democracy in Turkey. Nations and Nationalism. 17(2), 318-336.

Korkmaz, F. (2017). Neo-liberalizm bağlamında: sosyal bilgiler öğretim programının politik bir metin olarak incelenmesi. Eğitimde Nitel Araştırmalar Dergisi, 5(1), 29-57.

Köprülü, S. (2008). Cumhuriyetten günümüze temel eğitim matematik dersi öğretim programlarının eleştirel ve yaratıcı düşünme becerileri açısından incelenmesi. (Yayımlanmamış Yüksek Lisans Tezi), Hacettepe Üniversitesi Eğitim Bilimleri Enstitüsü, Ankara

Levy, P. (2001). Cyberculture. Minneapolis: University of Minnesoto Press.

Louise, S. (1989, Kasım). The image of other: Media support for a pluralistic curriculum. Annual Conference of the Community College General Education Association, New York, https://eric.ed.gov/?id=ED311972 (18 Kasım, 2018)

Maarif Vekaleti (1924). Illk mektep müfredat programı. Çeviren: H. Alp. İstanbul: Nobel Yayınları

Maarif Vekaleti (1926). ilk mektep müfredat programı. İstanbul: Devlet Matbaası

McConnell, F. (2008). Inventing pluralistic education. (Yayımlanmamış Doktora Tezi), Indiana University, Indiana

Milli Eğitim Bakanlığı [MEB] (1936). ilkokul programı. Ankara: Milli Eğitim Basımevi.

Milli Eğitim Bakanlığı [MEB] (1948). ilkokul programı. Ankara: Milli Eğitim Basımevi.

Milli Eğitim Bakanlığı [MEB] (1962). Illkokul programı taslağı. Ankara: Milli Eğitim Basımevi.

Milli Eğitim Bakanlı̆̆ı [MEB] (1968). Ilkokul programı. Ankara: Milli Eğitim Basımevi.

Milli Eğitim Bakanlığı [MEB] (1990). Sosyal Bilgiler Dersi Öğretim Programı. Ankara: Milli Eğitim Bakanlığı İlköğretim Genel Müdürlüğü.

Milli Eğitim Bakanlığı [MEB] (1998). Sosyal Bilgiler Dersi Öğretim Programı. İstanbul: Milli Eğitim Bakanlığı.

Milli Eğitim Bakanlığı [MEB] (2005). illkokul sosyal bilgiler dersi öğretim programı. Ankara: Milli Eğitim Basımevi.

Milli Eğitim Bakanlığı [MEB] (2015, Eylül). İlkokul sosyal bilgiler dersi öğretim programı. 18 Kasım 2018 tarihinde w.w.w. ttk.gov.tr adresinden erişilmiştir.

Milli Eğitim Bakanlığı [MEB] (2018, Eylül). İlkokul sosyal bilgiler dersi öğretim programı. 18 Kasım 2018 tarihinde w.w.w. ttk.gov.tr adresinden erişilmiştir.

Merey, Z. (2015). Illköğretim sosyal bilgiler öğretiminde vatandaşlık ve insan hakları eğitimi. M. Safran (Ed). Sosyal bilgiler öğretimi (s.719-742) içinde. Ankara: Pegem Akademi Yayıncılık.

Merriam, S. B. (2013). Case study research in education: A qualitative appoach. San Francisco: Jossey-Boss.

Miles, M. B. ve Huberman, A. M. (1994). Qualitative data analysis: An expanded sourcebook. New York: Sage. 
Motamed, H. R., Yarmohammadian, M. H. ve Yousefy, A. (2013). Comparative study of pluralistic vs unitarianism approaches concerning elements of curriculum. Procedia Social and Bhevioral Science, 83, 831-835.

Oğuz, A. K. (2007). Fedakar eş, fedakar yurttaş: Yurttaşlık bilgisi ve yurttaşlık eğitimi, 1970-1990. İstanbul: Kitap Yayınevi.

Öcal, A. ve Yakar, H. (2015). 1968-2005 sosyal bilgiler dersi programlarında küresel farkındalık eğitimi. Abant izzet Baysal Üniversitesi Eğitim Fakültesi Dergisi, 15 (USBES Özel Sayısı I), 307-327.

Özbudun, E. (2014). AKP at the crossroods: majoritarian drift. South European Society and Polities, 19(2), 156167

Özoğlu, M. (2012). Yükseköğretime geçiş ve özel dershaneler. Eğitime Bakış, 23, 47-57.

Öztürk, C. (2010). Cumhuriyet döneminde öğretmen yetiştirmede model arayışları. M. A. Parlak (Haz.), Cumhuriyet dönemi eğitim politikaları sempozyumu bildiriler kitabı (s.283-316) içinde. Ankara: Atatürk Araştırma Merkezi.

Pinar, W. (1999). Contemporary curriculum discourses: Twenty years of JCT. New York: Peter Lang.

Pinar, W. (2003). The internationalization of curriculum studies. New York: Peter Lang.

Pinar, W. (2004). What is curriculum theory. London: Lawrance Erlboum Associates Publishers.

Pinar, W., Reynolds, W., Slattery, P. ve Taubman, P. (1995). Understanding the curriculum: An introduction to historical and contemporary curriculum discourses. New York: Peter Lang.

Polat, E. G. (2011). Osmanlı'dan günümüze vatandaşlık anlayışı. Ankara Barosu Dergisi, 3, 127-157.

Safran, M. (2010, Ağustos). Cumhuriyet dönemi eğitim politikaları ve tarih öğretimi. M. A. Parlak (Haz.), Cumhuriyet dönemi eğitim politikaları sempozyumu bildiriler kitabı (s.395-406) içinde. Ankara: Atatürk Araştırma Merkezi.

Safran, M. (2011). Sosyal bilgiler öğretimine bakış. B. Tay ve A. Öcal (Ed.). Özel öğretim yöntemleri ile sosyal bilgiler öğretimi (s. 2-16) içinde. Ankara: Pegem Akademi Yayıncılık.

Sakallığlu, Ü. C. (1996). Parameters and strategies of Islam state interaction in republican Turkey. International Journal of Middle East Studies 26(2), 231-251.

Sakallığlu, Ü. C ve Çınar, M. (2003). Turkey 2002: Kemalism, islamism and politics in the light of February 28 process. The South Atlantic Quarterly, 102 (2/3), 309-332.

Sakaoğlu, N. (2018). Türk eğitim tarihi. 11-20 yüzyıllar. İstanbul: Alfa Yayınları.

Sarıer, Y. (2010). Ortaöğretime giriş sınavları ve PISA sonuçları ışı̆̆ında eğitimde fırsat eşitliğinin değerlendirilmesi. Ahi Evran Üniversitesi Eğitim Fakültesi Dergisi, 11(3), 107-129.

Schachner, M. K. (2017). From equality and inclusion to cultural pluralism- Evaluation and effects of cultural diversity perspectives in schools. European Journal of Developmental Psychology, 16(1) 1-17.

Schwab, J. J. (1971). The practical: Arts of eclectic. Shool Peview, 79, 493-542.

Shavlik, D. L., Touchton, J. G. ve Pearson, C. S. (1989). The new agenda of women for higher education. Educating The Majority: Women Challenge Tradition in Higher Education, 73(4) 441-458.

Shevitz, S. L., \& Wasserfall, R. (2009). Building community in a pluralist high school. In A. Pomson \& H. Deitcher (Eds.), Jewish day schools, Jewish communities: A reconsideration (pp. 376-395). Oxford: Littman Library of Jewish Civilization.

Solomon, I. D. (1988). Strategies for implementing a pluralistic curriculum in the social studies. The Social Studies, 79(6), 256-259.

Sönmez, V. (2005). Hayat ve sosyal bilgiler öğretimi öğretmen kılavuzu. Ankara: Anı Yayıncılık

Şen, A. (2019). Vatandaşlık eğitiminde değişiklik ve süreklilikler: 2018 sosyal bilgiler eğitim programı nasıl bir vatandaşlık öngörüyor? Eğitimde Nitel Araştırmalar Dergisi, 7(1), 1-28.

Taş, H. (2018). Eğitim, öğretim ve bilim hizmetleri kolunda faaliyet gösteren sendikaların yenilenen öğretim programlarına ilişkin görüşlerinin programın ögeleri bağlamında karşılaştırmalı olarak incelenmesi. Uluslararası Sosyal Araştırmalar Dergisi. 11(57), 440-454.

Tazebay, A. (2000). Ilköğretim programları ve gelişmeler, Ankara: Nobel Yayınları

Tertemiz, N. (2000). Cumhuriyet döneminde ilköğretim. A. Tazebay (Ed.), ilköğretim programları ve gelişmeler, (s.27-124) içinde. Ankara: Nobel Yayınları.

Toland, J. D. (1988). Inca legitimation as a communication process. R. Cohen and J. Toland (Eds.), State formation and political legitimacy (s. 115-145) içinde. New Brunswick: Transaction Books.

Tural, M. (2006). Türk eğitim tarihine bakış. M. Hesapçığlu ve A. Durmuş (Eds.), Türkiye'de eğitim bilimleri: Bir bilanço denemesi. (s. 97-147) içinde. Ankara: Nobel Yayınları 
Türkoğlu, A. (2010, Ağustos). Cumhuriyet döneminde ilköğretimin gelişimi. M. A. Parlak (Haz.), Cumhuriyet dönemi eğitim politikaları sempozyumu bildiriler kitabı (s.77-96) içinde. Ankara: Atatürk Araştırma Merkezi.

Türkoğlu, A. ve Sarı, M. (2006). Cumhuriyetten günümüze program geliştirme çabaları. M. Hesapçığlu ve A. Durmuş (Eds.), Türkiye'de eğitim bilimleri bir bilanço denemesi (s.327-367) içinde. Ankara: Nobel Yayınları.

Ünal, F. ve Ünal, M. (2010). Türkiye'de orta öğretim programlarının gelişimi. Sosyal Bilimler Araştırmaları Dergisi. 5(1), 110-125.

Üstel, F. (2011). “Maktul vatandaş”ın peşinde II. Meşrutiyet’ten bugüne vatandaşlık eğitimi. İstanbul: İletişim Yayınları.

Weinstein, J. R. (2004). Neutrality, pluralism and education: civic education as learning about the other. Studies in Philosophy and Education, 23, 235-263.

Wofford, K. (1952). Türkiye köy ilkokulları hakkında rapor. Ankara: Milli Eğitim Basımevi.

Yapıcı, M. (2004). Ideoloji ve eğitim. Uluslararası İnsan Bilimleri Dergisi, 8(1), 1-8

Yelken, E., ve Büyükcan, T. (2015). Discussing the private tutoring centers without falling into the trap of agenda. Education, Science and Society Journal, 13 (50), 24-27.

Yıldııım, A. ve Şimşek, H. (2006). Sosyal bilimlerde nitel araştırma yöntemleri (6. bs). Ankara: Seçkin Yayıncılık. 